Katarzyna DUDA

Uniwersytet Jagielloński

k.duda@op.pl

(D) https://orcid.org/0000-0001-5303-3760

\title{
MITOLOGIA RADZIECKA \\ (BELETRYSTYKA I REPORTAŻ \\ ROSYJSKI XX I XXI WIEKU)
}

ABSTRACT Soviet Mythology (Russian Belles-Lettres and Non-fiction Literature in 20th and 21 st Century)

Soviet history, since just after the October Revolution until the present day, has been full of myths created by the communist ideology and politics. In the past, these numerous myths (together with utopias) helped people to believe in the existence of a paradise on the Earth. The most popular of these myths are the myth of the victim, the myth of a hero fighting for 'the peace in the whole world', the myth connected with the figure of a Leader, Teacher showing how people have to speak, behave and act, the myth of the Great Patriotic War... The last one is especially well known all over the world because Soviet politicians always consider themselves winners who had regained freedom. These days the Great Patriotic War myth is used or even overused in the Russian Federation because people are looking for an event which could connect all former Soviet nations. Books written by Russian authors are the proof of this tendency.

Key words: Soviet mythology, a myth of the Great Patriotic War, literature proof of the historical truth

Słowa kluczowe: mitologia radziecka, mit Wielkiej Wojny Ojczyźnianej, literatura - dowód prawdy historycznej 
G orbaczowowska pierestrojka oraz rozpad Związku Radzieckiego dla wielu, zwłaszcza tzw. statystycznych, obywateli przyniosły rozczarowanie i tęsknotę za wielką, imperialną przeszłością, kiedy to o potędze państwa świadczyły stałe podboje i ciągłe podporządkowywanie sobie nowych terytoriów. Od czasów zrzucenia jarzma mongolskiego Ruś, a potem Rosja podbijały wciąż kolejne obszary, co miało być dowodem potęgi państwa i dumy z przynależności do jego struktur. Według założeń imperialnych Rosja miała być państwem wielonarodowym, wielokulturowym i wielowyznaniowym. Czasy radzieckie pokazały, że żaden z powyższych składników wielkomocarstwowości nie gwarantuje stabilności tak w polityce zewnętrznej, jak i międzynarodowej. Wielość narodów i kultur nie zapewniła ich przyjaźni, a nawet pokojowego współistnienia, religia natomiast była tępiona i uważana za przejaw prymitywizmu kulturowego. Naród rosyjski, mający być równy pośród innych wchodzących w skład ZSRR, stał się pierwszym i „lepszym” od pozostałych etnosów. Miejsce prawdziwej wiary zastąpiła quasi-religia, a wiarę w jedynego Boga - idolatria z panteonem bóstw, bożków i herosów zmieniających się wraz ze zmianami aktualnego kursu partii bolszewickiej. A zgadza się to z jedną $\mathrm{z}$ wielu definicji mitu, podkreślającą, iż jest on opowieścią o istotach nadprzyrodzonych. Jest to tzw. etnoreligijna definicja mitu dotycząca opowiadań o bogach i istotach nad-

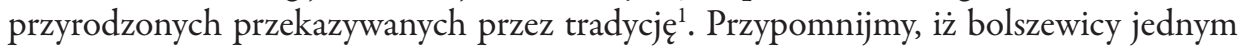
ze swych nadrzędnych zadań, już bezpośrednio po rewolucji październikowej, uczynili odcięcie się od tradycji i zapoczątkowanie tradycji własnej - wskazującej, że właściwe dzieje świata zaczęły się od czasów rewolucji - i w związku z tym wytworzyli wiele symboli poświadczających ich racje, a w rzeczywistości składających się na tzw. prawdę selektywną. Inna z definicji mitu określa ten ostatni jako literackie opowiadania, których treść została zaczerpnięta z mitologicznej tradycji, ale przetworzona przez pisarzy. I właśnie opierając się na tym określeniu, tzw. radzieccy kaprale od literatury mogli snuć rozliczne opowieści o ziemskim bogu - Stalinie, herosach rewolucji i wojny domowej, niepokonanych bohaterach wojennych zmagań i czekających na nich Penelopach, których szata tkana latami zamieniona została na karabin bądź kierownicę traktora w dłoni. Złamanie tak pojmowanego mitu przez twórców niepoddających się woli partii groziło rozpętaniem na nich nagonki. Tak stało się na przykład w przypadku Andrieja Płatonowa, pokazującego w swym opowiadaniu Powrót, którego akcja rozgrywa się tuż po II wojnie światowej, kobietę przekonaną o bohaterskiej śmierci swego męża - żołnierza i przyjmującej pod swój dach innego mężczyznę. Było to, zdaniem wulgarnosocjologicznych krytyków literackich, targnięciem się na mit wzorcowej, świętej wręcz rodziny radzieckiej.

Po przewrocie październikowym dążenie do wielkomocarstwowości i ekspansjonizmu przybrało na sile, choć nie było to, jak wspomniano wyżej, zjawisko nowe: Zawsze mamy wrażenie, że Rosja powinna stworzyć i pokazać światu coś niebywatego. Naród wybrany przez Boga. Odrębna droga Rosji... ${ }^{2}$ - powie jeden z bohaterów zbioru reporta-

M. Klik, Teorie mitu. Wspótczesne literaturoznawstwo francuskie (1969-2010), Warszawa 2016, s. 109. S. Aleksijewicz, Czasy secondhand. Koniec czerwonego cztowieka, przeł. J. Czech, Wołowiec 2014, s. 20. Wszystkie cytaty według tego wydania. W nawiasie podaję tytuł i numer strony. 
ży Swietłany Aleksijewicz Czasy secondhand. Koniec czerwonego cztowieka. Już bowiem od okresu panowania Iwana Groźnego, piszącego do Andrieja Kurbskiego: Jam jest car i wielki książę catej Rosji, ja decyduję o swoich poddanych ${ }^{3}$, imperialne dążenia Rosji przybrały na sile. Zdobywanie terytoriów i podporządkowywanie sobie poddanych kontynuował Piotr I. Badacze w związku z powyższym wnioskują, iż tzw. idea imperialna wpisana jest organicznie w mentalność Rosjan. Borys Jegorow pisze: $W$ świadomości narodu, w jego twórczości nie pojawit się ani jeden gtos, ani jeden znak protestu przeciwko wojnie zaborczej. Rozumie się jak gdyby samo przez się, że wielkie mocarstwo ma prawo do wszelkiego poszerzania swego terytorium i nie jest ważne, czy narody battyckie, Polski, Motdawii, Kaukazu, Azji Środkowej chca stać się częścią Rosji. Najważniejsze, że Rosja chce! Masowa, narodowa świadomość ani na chwile nie zamierzata staną́ na pozycjach podbitych nacji, istotny byt rosyjski punkt widzenia ${ }^{4}$.

Mit narodu wybranego stale więc towarzyszył Rosjanom. Cała historia państwa radzieckiego utkana jest z mitów podsycanych przez ideologię i rozwijanych za pośrednictwem propagandy, która nie tyle fałszowała rzeczywistość, ile przedstawiała fikcję jako fakty ${ }^{5}$. I tu spotykamy się z kolejną definicją mitu zakładającą, że mity nie są tylko opowieściami pochodzącymi z przeszłości i przekazywanymi przez pokolenia, ponieważ powstają również współcześnie - w odpowiedzi na aktualne wydarzenia, nie tylko religijne, ale także polityczne czy społeczne $e^{6}$. Bezpośrednio po zrywie październikowym 1917 r. był to mit rewolucji, związany z przeświadczeniem, że historia radziecka to w istocie swej historia rosyjska ${ }^{7}$, to przedłużenie dziejów całego państwa rosyjskiego, a chroniczna nędza, deficyt podstawowych towarów to nic innego jak właśnie znak narodu wybranego, który musi cierpieć, musi dźwigać swój (zastępujący chrześcijański krzyż) komunistyczny sierp i młot, aby rozniecić płomień rewolucji na cały świat i wcielić w życie ideę świetlanego jutra. Tak rozumiany mit rewolucji piastuje już we współczesnej Rosji m.in. bohaterka mikropowieści Wiktorii Tokariewej Mitość na cate zycie - Irina Guśko: Rozumiata, dlaczego w siedemnastym roku bolszewicy poderwali ludzi do rewolucji. „Grab zagrabione”. Gdyby teraz pojawit się nowy Lenin i wezwat do rewolucji, Irina znalaztaby się w jej pierwszym szeregu ${ }^{8}$. Irina utożsamia się całkowicie ze Związkiem Radzieckim, z mitem państwa-partii, który zastąpił mit rewolucji, popiera władzę i jej poczynania. Statystyczni obywatele radzieccy - w pełni oddani państwu - mogli żywić nadzieję, że władza, walcząc o zwycięstwo idei komunistycznej, troszczy się przede wszystkim o ich los, jednak celem nadrzędnym była właśnie wspomniana misja podarowania światu „świetlanego jutra” bez zwracania uwagi na to, jak ułoży się życie milionów ludzi. Celem polityki międzynarodowej Związku

Cyt. za: J. Afanasjew, Groźna Rosja, przeł. M. Kotowska, Warszawa 2005, s. 28.

4 B. Jegorow, Oblicza Rosji. Szkice z historii kultury Rosji XIX wieku, przeł. D. i B. Żyłkowie, Gdańsk 2002, s. 34.

5 R. Pipes, Rosja bolszewików, przeł. W. Jeżewski, Warszawa 2005, s. 45.

$6 \quad$ M. Klik, Teorie mitu..., s. 76.

7 M. Heller, Maszyna i śrubki. Jak hartowat się cztowiek radziecki, Warszawa 1989.

$8 \quad$ W. Tokariewa, Mitość na cate życie, przeł. I. Lewandowska, Warszawa 2006, s. 98. 
Radzieckiego nie byto zabezpieczenie interesów Rosji, narodu radzieckiego, czy federacji radzieckiej, ale zapewnienie zwycięstwa na catym świecie ideatów rewolucji bolszewickiej, komunizmu [...] ZSRR powstat niejako wytacznie dla uprawiania polityki zagranicznej, ponieważ polityka zagraniczna - czyli zwycięstwo komunizmu na świecie - byto jego gtównym celem?

Wśród zebranych w radzieckiej mitologii, a upowszechnianych przez upolitycznioną literaturę wysokonakładową, znajduje się mit Wodza-herosa, Mistrza i Nauczyciela, pokazującego, najczęściej metodą treningu, co i jak należy czynić. Najpierw był to Lenin, później Stalin. Po obaleniu kultu jednostki najważniejsze miejsce na radzieckim Olimpie znów zajął Władimir Iljicz Uljanow - należało go wielbić, inaczej bowiem znikłby „katechizm wiary”, a do tego dopuścić nie chciał wrośnięty mocno w struktury partyjne Michaił Gorbaczow. Nawet jednak już po upadku ZSRR „Komsomolskaja Prawda" z 21 kwietnia 2000 r. donosiła: Dozorczyni Ewa Plechanowa, lat 71, już od trzydziestu ośmiu lat dobrowolnie ochrania pomnik W.I. Lenina; odgania gotębie i wrony zanieczyszczajace wodza, wyciera nieprzyzwoite napisy, zostawione na Leninie przez jego rodaków, ma nawet pomocnika - psa Loszę, który nie pozwala podchodzić zbyt blisko do monumentu ${ }^{10}$. Okazuje się więc, że bałwochwalstwo to choroba społeczna, w Rosji przybierająca specyficzne formy. Rosjanie zawsze oddawali czemuś (albo komuś) cześć, by później obiekty owego hołdu niszczyć. Niegdyś wrzucano do Dniepru pogańskie bożki. Po rewolucji dewastowano cerkwie, przekształcając je w magazyny, by następnie bić pokłony przed Leninem i Stalinem.

Mity wpisane w ideologię i propagandę radziecką wprowadziły do umysłów obywateli potężny szum informacyjny i chaos poznawczy. Są one, co prawda, pierwszą formą objaśniania rzeczy i wszechświata, ale, jak pokazują choćby powyższe przykłady, wyjaśnianie to odbywa się nie dzięki odwołaniom do sfery ratio, lecz do uczuć i emocji. Według definicji archetypicznej mit jest wspólną wszystkim ludziom formą psychiczną, obdarzoną silnym ładunkiem emocjonalnym ${ }^{11}$. Określając zatem ogólnie ideologię jako zestaw jedynych możliwych odpowiedzi na wszystkie pytania, ideologię radziecką można nazwać systemem, który na wszelkie pytania daje odpowiedzi irracjonalne, mitologiczne ${ }^{12}$.Zdaniem zwolenników definicji socjologicznej, która bodaj najpełniej oddaje sens i rolę mitologii radzieckiej, mit pełni funkcję komunikacyjną, to znaczy jest jednym ze sposobów spotecznej komunikacji, przekazujacym przede wszystkim sensy $i$ znaczenia. Po trzecie, mit petni funkcje normatywna, to znaczy wskazuje podstawowe dla spoteczeństwa normy i wartości; po czwarte sensotwórcza, to znaczy nadaje znaczenie i sens poszczególnym aspektom rzeczywistości spotecznej. Po piąte [...] petni funkcje uniwersalizujaca - pozwala grupom spotecznym sytuować się wobec problemów spotecznych; po szóste integracyjna - określając powinności jednostki wobec spoteczeństwa; po siódme

P. Ziółek, Idea imperium, Warszawa 1997, s. 167.

10 „Комсомольская правда” 2000, 21 апреля, [online] http://magazines.rus.ru/volga/recens.html, 11 V 2008. Tłumaczenie z tekstów obcojęzycznych - jeśli nie podano inaczej - K.D.

11 A. Gieysztor, Mitologia Stowian, Warszawa 2006, s. 46.

12 M. Heller, Maszyna i śrubki..., s. 129. 
manipulacyjna [podkreślenie - K.D.] - ukrywając narzędzia sprawowania kontroli $i$ wtadzy nad spoteczeństwem ${ }^{13}$.

Mitologia pozwala wierzyć w nieistniejące i negować realność. Irrealność mitu utrudnia jego zdemaskowanie za pomocą logiki, ułatwia za to posługiwanie się kłamstwem i, co najgroźniejsze, utrwalanie tego ostatniego w pamięci pokoleń. Fenomen ten, rozpatrywany na gruncie filozofii, psychologii, socjologii, zwykło się obecnie nazywać pamięcią zbiorową. Według Barbary Szackiej jest ona zbiorem wyobrażeń cztonków zbiorowości o jej przesztości, o zaludniajacych ja postaciach i minionych wydarzeniach, jakie w niej zaszty, a także sposób ich upamiętniania i przekazywania o nich wiedzy uważanej za obowiązkowe wyposażenie cztonka tej zbiorowości $i^{14}$. W ten sposób zrodził się model socjalny „syn przeciwko ojcu”, negujący autorytet starszeństwa, doświadczenia, na rzecz autorytetu siły ${ }^{15}$. Najlepszym tego przykładem, ikoniczną wręcz wersją chłop$\mathrm{ca}$ - radzieckiego herosa, który w imię świetlanego jutra doniósł na własnego ojca - jest Pawlik Morozow. Fałsz obecny w licznych opowieściach o nim zawarl, nazywany przez Lucjana Suchanka „tropicielem czerwonych mitów”" ${ }^{16}$, przedstawiciel trzeciej fali emigracji rosyjskiej - Aleksander Zinowiew - w swoim demaskatorskim eseju Donosiciel 001, czyli Pawlika Morozowa wyniesienie na ottarze $e^{17}$.

W państwie radzieckim, szczególnie bezpośrednio po przewrocie październikowym oraz w okresie stalinizmu, żywy był mit stworzenia świata przez człowieka. Chaos mieli przemienić w Kosmos Marks, Engels, Lenin i Stalin. Za nimi podążali przedstawiciele kultury tworzący tzw. wzorce neobabilońskie, które świadczyły o zawłaszczaniu sobie praw boskich przez człowieka. I tu dochodzi do głosu definicja polityczna mitu, według której mit jest opowiadaniem założycielskim, tzn. jego narracja objaśnia początki, czyli zdarzenia doprowadzające do ukształtowania danej rzeczywistości (w interesującym nas przypadku: Kraju Rad). Według zwolenników tej definicji mit może wyrażać pewna ideę, dzięki której spoteczność realizuje swoje marzenia o wielkości - być propagandowa opowieścia petniaca określona funkcje polityczno-spoteczna, rodzajem ktamstwa fatszujacym prawdziwy przebieg wydarzeñ ${ }^{18}$. W literaturze radzieckiej takich właśnie ludzi - „stwórców” - ukazał Aleksiej Gastiew w poemacie Wieża, w architekturze tworami bogoczłowieka były niezrealizowane projekty pomnika III Międzynarodówki konstruktywisty Władimira Tatlina oraz Pałacu Rad, zwieńczonego olbrzymią statuą Lenina i mającego zastąpić wyburzoną Świątynię Chrystusa Zbawiciela. Demitologizację tezy o człowieku-Stwórcy wyeksponował już w 1929 r., w swym utworze Wykop, Andriej Płatonow: budowany przez proletariuszy wszechproletariacki dom nigdy nie

13 M. Klik, Teorie mitu..., s. 359.

14 B. Szacka, Czas przeszty, pamięć i mit, Warszawa 2006, s. 19.

15 J. Sadowski, Rewolucja i kontrrewolucja obyczajów. Rodzina, prokreacja i przestrzeń życia w rosyjskim dyskursie utopijnym lat 20. i 30. XX wieku, Łódź 2005, s. 57-58.

16 L. Suchanek, Anioty, biesy i prawda. Pisarstwo Jurija Drużikowa, Kraków 2007, s. 225.

17 J. Drużnikow, Pawlika Morozowa wyniesienie na ottarze, [w:] tegoż, Rosyjskie mity. Od Puszkina do Pawlika Morozowa, przeł. F. Ociepka, M. Putrament, Warszawa 1998, s. 143-279.

18 M. Klik, Teorie mitu..., s. 164. 
powstanie: tworzony bowiem będzie na nieszczęściu i krzywdzie, ale przede wszystkim na śmierci dziecka symbolizującego przyszłość. Nie będzie, tak jak to było w zamierzeniu Tatlina czy twórców Pałacu Rad, sięgać wzwyż, ku chmurom i niebu, nie będzie miał nawet usytuowania horyzontalnego, zawsze pozostanie na etapie tytułowego wykopu, znamionującego przeciwieństwo ruchu wzwyż, schodzenie do piekieł. Pomimo tego jednak, podobnie jak wszystkie mity, tak i radziecki mit o stworzeniu świata kreował własną etykę, która dawała natchnienie milionom i z roku na rok rozprzestrzeniała się coraz bardziej. Opierała się ona na ciągłej walce, w której nie było miejsca na litość ani dla rzeczywistych, ani dla domniemanych wrogów. Była to więc etyka bojowników. Nieprzypadkowo w szkolnictwie radzieckim tak wiele miejsca poświęcano wychowaniu wojskowo-patriotycznemu. Chłopcy piastowali dumę z możliwości bycia żołnierzem, a między pojęciami „państwo” i „ojczyzna” postawiono znak równości. Bohaterowie reportaży Aleksijewicz zaświadczą: Wyrośliśmy pośród katów i ofiar... Dla nas życie razem jest normalne. Nie ma granicy między stanem pokoju a stanem wojny. Wojna jest zawsze (Czasy secondhand..., s. 37), albo: Przywykliśmy do tego, że ludzi trzeba bić, bez bicia się nie poradzi (Czasy secondhand..., s. 50).

Wróg stał się więc pojęciem mitycznym, stale obecnym w ideologii radzieckiej. Stawał się nim, w zależności od aktualnego kursu partii, „burżuj”, kułak, podkułacznik, Niemiec, obywatel walczących Węgier. Wrogiem uniwersalnym zaś był Żyd. Zgodnie z potrzebami władzy to wzmacniano, to znów osłabiano nienawiść do Żydów. Prawdą jest, iż wielu Żydów tępionych za czasów cara przypisało rewolucji moc niemal oczyszczającą, siłę, która pozwoli na zniesienie narodowościowych ograniczeń, zaprzestania tworzenia wydzielonych stref osiedlenia i limitowanych przyjęć na uczelnie młodzieży żydowskiej. Tak początkowo postrzegali przewrót 1917 r. także wielcy artyści: malarz Marc Chagall bądź mistrz noweli - Izaak Babel. Ten ostatni w cyklu utworów Opowiadania odeskie przełamał stereotyp Żyda - wiecznego tułacza, ciągle pokornego i bijącego pokłony przed carem. Dodajmy, iż niebawem rewolucyjny entuzjazm Babla drastycznie osłabł. Sam twórca został rozstrzelany. Inny pisarz - Fridrich Gorensztejn - wskazywał na konieczność zachowania swych korzeni, pielęgnowania tradycji. Autor Psalmu stał się jednym z wielu przedstawicieli trzeciej fali emigracji rosyjskiej, a ta ostatnia była w dużej mierze fenomenem żydowskim. Głośnym echem odbiła się w historii ZSRR nagonka na tzw. kosmopolitów (za takich uważano zwłaszcza Żydów) i związany z nią „spisek lekarzy” kremlowskich. Pisze o tym m.in. Ludmiła Ulicka w powieści Przypadek Doktora Kukockiego, wprowadzając ten motyw poprzez następujący fragment: W styczniu 1953 w catym kraju odbywaty sie zebrania oburzonych obywatel, a w ochronie zdrowia przedsięwzięcia tego rodzaju organizowane byty ze szczególnym zapatem. Wszyscy zajmujacy znaczniejsze stanowiska byli obowiąani się wypowiedzieć i potępić przestępców. Po raz pierwszy Pawta Aleksiejewicza oświecita prosta myśl, że wszystkich lekarzy, co do jednego, wciaga się we wspótudziat w haniebnym oskarżeniu. On sam nie miat najmniejszych wątpliwości co do catkowitego braku winy lekarzy. Pawet wpadt w gtęboka depresję i po raz pierwszy w życiu zaczat myśleć o samobójstwie $e^{19}$. Spisek lekarzy

19 L. Ulicka, Przypadek doktora Kukockiego, przeł. B. Reszko, Warszawa 2006, s. 139. 
związany był z następnym etapem planowanej czystki. W styczniu 1953 r. aresztowano pod zarzutem zamordowania Żdanowa i popełnienia innych zbrodni antyradzieckich wielu kremlowskich lekarzy, w większości noszących żydowskie nazwiska. Było to posunięcie, które mogło posłużyć za pretekst do przeprowadzenia zakrojonej na coraz większą skalę czystki „zdrajców” pracujących na rzecz amerykańskiego imperializmu i syjonizmu oraz dążących do zniszczenia międzynarodowego komunizmu ${ }^{20}$. Za pretekst do aresztowania lekarzy, o czym pisze Ulicka ${ }^{21}$, posłużył donos rentgenologa kremlowskiego szpitala, doktor Lidii Timaszuk, pracującej jednocześnie dla Ministerstwa Bezpieczeństwa Państwowego. Oskarżonych poddano bestialskim torturom, po których przyznali się do udziału w spisku, mającym na celu zgładzenie przywódców partii i państwa, a także najwyższego dowództwa wojskowego, poprzez stosowanie umyślnie nieprawidłowych metod leczenia ${ }^{22}$. Historia sama jednak dopisała finał tej bulwersującej sprawy. Już po śmierci Stalina, 4 kwietnia 1953 r., opublikowano bez jakichkolwiek komentarzy komunikat Ministerstwa Spraw Wewnętrznych ZSRR, iż sprawa „zabójców w białych fartuchach” była prowokacją spreparowaną przez kierownictwo dawnego Ministerstwa Bezpieczeństwa Państwowego i że oskarżeni lekarze są niewinni.

Autorka Przypadku doktora Kukockiego w innych swoich powieściach (Daniel Stein - ttumacz, Medea i jej dzieci ${ }^{23}$ ) stara się dowieść, iż spełniając warunki tolerancji i respektowania Innego, możliwe było na terenie ZSRR wspólistnienie wielu kultur, a tym samym choćby częściowe przełamanie mitu monolityczności państwa radzieckiego. Ten ostatni włączał w siebie właśnie mit wroga dążącego do zburzenia jedności i jednocześnie usprawiedliwiał, jako jedyną możliwość, wojnę przeciwko wszystkim, którzy zagrażają monolitowi. Przekształcenie jedności w mit przekształca równocześnie, co próbowaliśmy wykazać powyżej, wroga w pojęcie mityczne, irracjonalne. Na przykład decyzja na wyrażenie zgody, aby Żydzi wyjechali z ZSRR, przyjęta na początku lat 70. $\mathrm{XX}$ w. - to jedna z najbardziej udanych akcji radzieckich mitotwórców ${ }^{24}$. W kraju, z którego nikt nie ma prawa wyjechać, grupa mająca taką możliwość staje się wrogiem występującym przeciw ,jedności”, przeciw monolitowi.

Radziecka prasa wyjaśniała brak towarów, złą jakość produktów i niewystarczającą ilość dróg - ostro i boleśnie odczuwane w Republice Rosyjskiej - korupcją, bezczynnością i rozkosznym życiem obywateli republik nieradzieckich. W środkach masowego przekazu rzadko podawano informacje o malwersacji, przestępstwach, a jeśli już tak się działo, to dotyczyły one zwykle republik kaukaskich czy środkowoazjatyckich

20 M. Malia, Sowiecka tragedia. Historia komunistycznego imperium rosyjskiego 1917-1991, przeł. M. Hułas, E. Wyzner, Warszawa 1998, s. 348.

${ }_{21}$ Zob. K. Duda, Wspótczesna literatura rosyjska wobec historii (nowy realizm Ludmity Ulickiej), „Prace Komisji Kultury Słowian PAU” 2008, t. 7: Kultura i polityka, s. 45-63.

22 M. Heller, A. Niekricz, Utopia u wtadzy. Historia Zwiazku Sowieckiego, t. 2, przel. A. Mietkowski, Wrocław 1989, s. 167.

23 Zob. K. Duda, Narody Kraju Rad. Wspótistnienie i zatomizowanie kultur (twórczość Ludmity Ulickiej), „Politeja” 2014, nr 5 (31/1), s. 133-153.

$24 \quad$ M. Heller, Maszyna iśrubki..., s. 121. 
albo osób z żydowskimi nazwiskami ${ }^{25}$. Uczucia narodowe były, wespół z religią, najważniejszymi punktami oparcia, pozwalającymi sprzeciwiać się presji radzieckiej ideologii, włączeniu w magiczny krąg mitologii radzieckiej. Dlatego prowadzona była walka z nacjonalizmami narodów nierosyjskich, których nie sposób wykorzystać dla mitotwórstwa, a także z tymi religiami, które nie pozwalają na zasymilowanie się i odmawiają służenia państwu ${ }^{26}$. Konflikt między wielonarodowościowym państwem radzieckim i mitem monolitu-jedności starano się przezwyciężyć poprzez zatwierdzenie jednocześnie koncepcji „państwa ogólnonarodowego” i „narodu rosyjskiego” jako modelu, jako przykładu dla innych narodów. W dwoistości koncepcji tkwiło jednak zagrożenie dla monolitu. Konieczność mitu monolityczności jako formy legitymizacji władzy wyjaśnia ostre napięcia, jakie istniały w krajach komunistycznych. Nastroje separatystyczne stały się jedną z przyczyn upadku ZSRR, a tym samym zburzenia mitu monolitu. Po roku 1991 dały o sobie znać ostre spięcia pomiędzy poszczególnymi republikami. Na skutek tych konfliktów ucierpieli nie tylko obywatele republik chcących odzyskać wolność, ale i sami Rosjanie.

Problemowi upadku mitu monolityczności również dała świadectwo współczesna beletrystyka rosyjska ${ }^{27}$ : mieszkająca początkowo w Baku Irina Guśko - bohaterka wspomnianego już utworu Tokariewej - opisuje tragedię rdzennych Rosjan, jaka rozegrała się na skutek konfliktów narodowościowych: Irina czuta się winna nie wiadomo dlaczego. Bata sie jeździć autobusem, bata się chodzić do sklepu po zakupy. Patrzono na nia z lekceważacym obrzydzeniem. Traktowano po chamsku. Ruski dżulab [...] Nienawiść - to jak epidemia. Jest bezgraniczna. Z Ormian przerzucita się na Rosjan. Niewierni muszq odejść z ziemi muzutmanów. Azerbejdżan dla Azerów. Wszyscy inni niech jadq do siebie ${ }^{28}$. A więc o swych aspiracjach nie zapomnieli też Ormianie, domagając się zwrotu przyznanego w 1923 r. Azerbejdżanowi, a zamieszkanego w 80\% przez Ormian Górskiego Karabachu. Dla poparcia tych żądań odbyła się w Erewanie potężna demonstracja. Reakcją na nią była pięć dni później rzeź Ormian w azerskim Sumgaicie. Konflikt przybrał wyjątkowo krwawą postać i trwał przez następne lata ${ }^{29}$. Gorbaczowowska pierestrojka zatem nie wypracowała żadnych mechanizmów, które pozwoliłyby konfliktom narodowościowym (w państwie totalitarnym sztucznie tłumionym) znaleźć ujście inne niż późniejsze krwawe rozprawy. Nie wypracowała zresztą nawet mechanizmów zapobiegających podsycaniu tych konfliktów przez Moskwę ${ }^{30}$. Mit monolitu państwa upadał, niosąc ze sobą liczne ofiary, rodząc nowe stereotypy i czyniąc coraz ostrzejszą linię podziału między Swoim a Obcym. A oto, co na ten temat

\footnotetext{
25 Tamże.

26 Tamże.

27 K. Duda, „Nowi Rosjanie” i statystyczny obywatel. Wspótczesna Rosja w literaturze popularnej (Oksana Robski i Wiktoria Tokariewa), [w:] Kultura rosyjska w ojczyźnie i diasporze. Księga jubileuszowa dedykowana Profesorowi Lucjanowi Suchankowi, t. 2, red. K. Duda, Kraków 2008, s. 201-211.

W. Tokariewa, Mitość na cate życie, s. 53.

29 J. Smaga, Rosja w 20 stuleciu, Kraków 2002, s. 279.

30 J. Sadowski, Dokad zmierzasz, trojko?, „Znak” 2005, nr 10, s. 12.
} 
pisze Aleksander Sołżenicyn: Ludzie żyjacy w swoich miejscowościach, w których oni sami, a przed nimi ich ojcowie i dziadowie spędzili cate życie, obudziwszy się pewnego dnia, nagle dowiedzieli się, że mieszkają za granica, że sa niepożadanymi, odpychanymi, a nawet znienawidzonymi cudzoziemcami. Jak można z czymś taki się oswoić? Przetrawić w sercu, w piersi, w gtowie? Sowiecka "przyjaźń narodów", o której styszeliśmy tyle ód i ballad, w mgnieniu oka wyszczerzyta zęby i okazata się wrogościa, która byta ttumiona, ale, jak widać, nigdy nie ustata ${ }^{31}$.

$\mathrm{Z}$ powagi problemów mniejszości narodowych, odgrywających ważną rolę w mitycznym państwie-monolicie, nie zdawał sobie sprawy Michaił Gorbaczow, ufając zapisanym w partyjnych dokumentach słowom Leonida Breżniewa, że różne narodowości stanowią spójne i homogeniczne społeczeństwo radzieckie ${ }^{32}$. Republiki wykorzystywane były natomiast przez cały czas istnienia ZSRR jako dostarczycielki swych bogactw naturalnych i surowców dla Centrum. Gorbaczow wiedział, że krwawe tłumienie zrywów narodowościowych odetnie jego państwo od napływających z Zachodu kredytów, a on sam utraci prestiż. Ponadto $\mathrm{w}$ armii radzieckiej służyli obywatele różnych narodowości i zmuszenie ich do walki ze współbraćmi graniczyłoby z naiwnością. Nabrzmiałego problemu etnicznego nie dało się też ukryć bądź zatuszować innymi sprawami, gdyż na skutek gorbaczowowskiej gtasnosti media nagłaśniały konflikt ${ }^{33}$. W republikach nieradzieckich, jak już nadmieniono, znajdowało się też bardzo wielu, celowo (dla stworzenia monolitu proletariackiego) sprowadzonych tutaj Rosjan. Rdzenni mieszkańcy republik nazywali ich cudzoziemcami i niewolnikami. Zdarzały się przypadki podpalania na cmentarzach rosyjskich mogił i niszczenia cerkwi, zabraniano używać języka rosyjskiego. Kwestie te znalazły odzwierciedlenie również w powieści współczesnego pisarza rosyjskiego Romana Senczina Rodzina Jottyszewów ${ }^{34}:$ Tuwa, do której zjeżdżali nieraz różni specjaliści (wyższa pensja, szybszy awans, wszelkie ulgi, szybsza kolejka po mieszkanie), leży bardziej na potudnie, po drugiej stronie Gór Sajańskich. Ale pod koniec lat osiemdziesiatych, jak w wielu republikach Zwiazku Radzieckiego, $w$ Tuwie zaczęty się konflikty narodowościowe i Ukraincy, Gruzini, Rosjanie, wszyscy niebędacy rdzennymi mieszkańcami powyjeżdzali stamtąd. Niektórzy uciekali ze stepowych wsi i osad, zostawiajac prawie caty dobytek, przerażeni groźbami wyrżnięcia czy spalenia żywcem ${ }^{35}$.

Mimo krzywd zadanych przez totalitaryzm w jego wersji komunistycznej, mimo prób demitologizacji systemu, ludzie, piastując szczególny rodzaj „mitu różowej przeszłości"36, odczuwają tęsknotę za imperium. Przejawia się to m.in. w specyficznej odzie na cześć imperium wyrażonej ustami bohaterki utworu Mitość na cate życie: Gdzieżeś

31 A. Sołżenicyn, Rosja w zapaści, przeł. J. Zychowicz, Warszawa 1999, s. 42.

32 M. Malia, Sowiecka tragedia..., s. 477.

33 J. Gajdar, Upadek imperium. Nauka dla wspótczesnej Rosji, przeł. H. Chłystowski, Warszawa 2015, s. 346-352.

34 Zob. K. Duda, „...chciat zakasać rękawy i zaczać budować nowy, duży dom...”. Roman Sienczyn „Rodzina Jottyszewów”, [w:] tejże, Szkice o prozie rosyjskiej XXI wieku: Ulicka, Szyszkin, Pielewin, Minajew, Sienczyn, Kuricyn, Starobiniec..., Kraków 2017, s. 187-215.

35 R. Senczin, Rodzina Jottyszewów, przeł. M. Hornung, Warszawa 2015, s. 56.

36 J. Szacki, Spotkania z utopia, Warszawa 2000, s. 54. 
tak umitowany Zwiazku Radziecki? Kim jesteś mój dzisiejszy kraju, który przemieniteś mnie w bezdomna stużaca? [...] Dobrze bytoby zasnać, obudzić się i zobaczyć, że znowu jest tak, jak już byto. Wszyscy sa równi. Biuro polityczne niczym apostotowie Chrystusa. Nikt o nich nic nie wie ${ }^{37}$. A zatem: dawne czasy zdążyły już ulec mitologizacji. Była to tęsknota za „porządkiem” panującym w czasach Stalina, za rzekomą stabilizacją życiową za Breżniewa, za respektem, jaki radziecki arsenał militarny wzbudzał u zachodnich przeciwników, za krzepiącą ideologią imperium. Tego rodzaju sentyment za minionymi czasami stał się potężnym motorem reakcji politycznej w Rosji. W świadomości wielu milionów Rosjan dzieje ich kraju od czasu objęcia władzy przez Gorbaczowa stanowią pasmo kolejnych strat terytorialnych i związanych z tym upokorzen ${ }^{38}$. Ałła Siergiejewa tęsknotę za przeszłością i dawnym radzieckim imperium tłumaczy nieudanymi i pospiesznymi reformami, poczuciem krzywdy, jakie się odezwało w narodzie rosyjskim, oraz utratą nadziei na zmianę. Tęsknota ta przejawia się zatem w chęci powrotu do czasów młodości kojarzonych zazwyczaj z lepszymi momentami w życiu, z nadzieją, że wszystko jeszcze może się zdarzyć, że wszystko jeszcze przed nami. Jest więc związana ze specyficznym odczuwaniem minionego czasu. Rosjanie bowiem, mimo wszystko, wolą patrzeć w przeszłość niż w przyszłość, a ich życiu bezustannie towarzyszy nostalgia ${ }^{39}$. Swietłana Bojm natomiast rozpatruje odczuwanie nostalgii nie jako lokalną chorobę narodu rosyjskiego, a fenomen kultury światowej, objawiający się próbą powstrzymania upływającego czasu, chęcią powrotu do innych okresów historycznych lub innej przestrzeni mitologicznej. Nostalgia jest niejako reakcją obronną na mijające bezpowrotnie życie i pragnienie stabilności, której nie możemy odnaleźć w obecnej rzeczywistości ${ }^{40}$. Pobrzmiewałyby więc we współczesnej Rosji idee (świadomych, bądź częściej, nieświadomych) zwolenników definicji etnoreligijnej mitu autorstwa francuskiego filologa Georges'a Dumézila. Twierdził on, że mit nie jest pozbawionym znaczenia wytworem wyobraźni, przekazuje bowiem i uprawomocnia główne zasady, na których opiera się organizacja religijna i polityczna społeczeństwa. W większości przypadków mit obrazuje więc historię i religię danej społeczności, tłumacząc istniejący porządek społeczny i polityczny ${ }^{41}$. Ponieważ więc w Federacji Rosyjskiej religia nie zdążyła się jeszcze odrodzić, a radziecka quasi-religia zanika, panteon nowych bóstw zaczyna się dopiero zapełniać, to mit wciąż organizuje pamięć tak zbiorową, jak i indywidualną, dokonując szczególnego rodzaju przefiltrowania historii poprzez wyrzucanie z magazynu pamięciowego faktów niewygodnych i pozostawianie w nim tego, czego ludność pragnie i oczekuje.

Wielkie imperia, jak zaświadcza historia, rozpadają się (bądź raczej ulegają rozkładowi) na przestrzeni wielu lat. Obywatele byłych supermocarstw powoli, stopniowo, przyzwyczajają się do bycia statystycznymi mieszkańcami równie statystycznego,

\footnotetext{
W. Tokariewa, Mitość na cate życie, s. 99.

38 D. Remnick, Zmartwychwstanie. Walka o nowa Rosje, przeł. M. Słysz, Warszawa 1997, s. 96.

39 А. Сергеева, Русские. Стереотипь поведения, традиции ментальность, Москва 2005, s. 269.

40 С. Бойм, Общие места, Москва 2002, s. 297.

41 M. Klik, Teorie mitu..., s. 34.
} 
niewyróżniającego się niczym szczególnym państwa. Natomiast dla większości Rosjan, którym propaganda i manipulacja nie pozwalała dojrzeć kruszenia się imperium, rozpad ZSRR w $1991 \mathrm{r}$. wydawał się wydarzeniem nagłym, niespodziewanym i pozbawiającym ich złudzeń co do własnej wyjątkowości: Taki kraj oddali! Mocarstwo! Bez jednego strzatu...(Czasy secondhand..., s. 95). Ludzie zostali zawieszeni w próżni ideowej, zapanowała pustka aksjologiczna, zabrakło bazy, na której można by się oprzeć: Cate życie przeżytam z wiara, że jesteśmy najszcześliwsi, bo urodziliśmy się w przepięknym, zupetnie wyjatkowym kraju (Czasy secondhand..., s. 95) powie jedna z interlokutorek Aleksijewicz. Ludzie poczuli się więc oszukani, znaleźli się w sytuacji sierot pozbawionych rodzicielskiej opieki i dachu nad głową. Brak bezpieczeństwa poszczególnych obywateli oznaczał również groźbę ich buntu bądź całkowitej apatii, a w konsekwencji rozkład struktur składających się na współczesną Federację Rosyjską.

W celu zapobieżenia dalszej eskalacji konfliktów i umocnienia Rosji zarówno na arenie międzynarodowej, jak i przede wszystkim w obszarze polityki wewnętrznej po raz kolejny zwrócono się do przeszłości i do wykorzystania mitu mającego pełnić funkcję scalającą, jednoczącą zatomizowane społeczeństwo. Mitem łączącym Kreml i wieloetniczną resztę kraju stała się Wielka Wojna Ojczyźniana. W moderowanej przez władzę pamięci zbiorowej okres zamknięty datami 22 VI 1941 - 9 V 1945 stał się sferą sacrum, organizującą świadomość ludzi. Propagandowe mitotwórstwo ponownie zaczęło wypierać prawdę. W głębinach niepamięci znalazł się faktyczny początek II wojny światowej: 1 września 1939 r. - napaść Hitlera na Polskę, 17 września - najazd wojsk radzieckich na Polskę. Ukryto też inne niewygodne fakty: przedłużającą się kampanię fińską, przygotowywanie przez Stalina projektu „Burza”, który miał wyprzedzić hitlerowski plan „Barbarossa”, grzech zaniechania wobec powstania warszawskiego, „doły śmierci” w Katyniu i w Kuropatach... Wyeksponowaniu podlegają jedynie wydarzenia wychwalające moc oręża radzieckiego i podkreślające zwycięską rolę ZSRR w pokonaniu nazistowskich Niemiec. Tak rozumiana polityka historyczna ma służyć scaleniu podlegającego rozproszeniu społeczeństwa, podkreślenia ciągłości pokoleń, związanych traumatycznym przeżyciem, jakim w tym przypadku jest wojna, oraz odbudowaniu tożsamości zbiorowej ${ }^{42}$ rozumianej tutaj jako próba odpowiedzi na pytania: „kim jesteśmy?”, „z czym/kim się identyfikujemy?”.

Jeden z rosyjskich badaczy fenomenu pamięci, socjolog Boris Dubin, dokonał próby rekonstrukcji tzw. „struktury kulturowego czasu Rosjan” oraz wyobrażenia o „przeżytym wspólnie czasie". Jak zauważa: [...] początkiem tego wspólnego czasu w świadomości masowej jest rewolucja październikowa, końcem zaś upadek ZSRR i wojna w Czeczenii; punktem centralnym catej struktury temporalnej jest zwycięstwo w Wielkiej Wojnie Ojczyźnianej ${ }^{43}$.

Po względnie liberalnym dla pamięci pokoleń okresie rządów Gorbaczowa władze rosyjskie (od czasu przejęcia urzędu prezydenta przez Władimira Putina) rozpoczęły

42 Zob. więcej: M. Dziekanowska, Pamięć a tożsamość zbiorowa, [w:] Pamięć jako kategoria rzeczywistości spotecznej, red. J. Styka, M. Dziekanowska, Lublin 2012, s. 29.

43 Cyt. za: O. Leontjewa, Badania nad pamięcia historyczna we wspótczesnej nauce rosyjskiej, przeł. A. Jaskólski, „Rocznik Instytutu Europy Środkowo-Wschodniej” 2015, z. 2, s. 31-32. 
proces wybielania historii Związku Radzieckiego. Miało to początkowo na celu ochronę interesów Rosji poza jej granicami, gdzie w wielu krajach nasilała się antyrosyjska polityka historyczna w szczególności w odniesieniu do II wojny światowej i okresu stalinowskiego. Zdaniem Aleksieja Millera, podstawą założeń polityki stała się normalizacja stalinizmu jako autorytarnego modelu przyspieszonej modernizacji $w$ warunkach „oblężonej twierdzy" i uzasadnienia wiodacej roli nowoczesnego autorytarnego lidera ${ }^{44}$. Tego rodzaju podejście podlegało zmianom w zależności od sytuacji wewnątrz kraju, a także na arenie międzynarodowej, nadal jednak można zaobserwować, iż jest ono aktualne. W związku z tym, jak już wielokrotnie zostało zaakcentowane, obecnie największy nacisk kładzie się na mitologizację Wielkiej Wojny Ojczyźnianej, podkreślając rolę, jaką Związek Radziecki odegrał w rzekomym przywracaniu stabilizacji w Europie i na świecie.

Michaił Niemcew, obok tzw. postpamięci smutku (nocmnaмsms горя) wyróżnia postpamięć dumy (nocmnamsmb ropдocmu) ${ }^{45}$. W tę ostatnią wpisuje się właśnie mit heroicznych walk z nazistami oraz osiągnięć epoki Stalina. Bez wątpienia przeżycia związane $\mathrm{z}$ wojną można uznać za traumatyczne. W odniesieniu do tego wydarzenia istnieje jednak wiele niewypełnionych przestrzeni pamięciowych funkcjonujących w świadomości społeczeństwa, a także ogólnopaństwowa propaganda niszcząca wspomnienia świadków tamtego okresu historycznego. Mówienie o prawdziwym przebiegu wojny i sytuacji w państwie w owym czasie było surowo zakazane, promowano natomiast zmitologizowane wydarzenia tworzone narzędziami propagandy. Borys Sokołow pisze: W historiografii sowieckiej Wielka Wojna Ojczyźniana zostata zmitologizowana w sposób groteskowy i niestety podobnie jest taktowana do dziś przez wspótczesna historiografie rosyjska. Dzisiejsza nowoczesna Rosja potrzebuje natomiast samokrytycyzmu narodowego i wyzbycia się mitologicznego spojrzenia na rzeczywistośćt ${ }^{46}$.

Władze radzieckie nie wyrażały zgody na publikację zgodnych z faktycznym stanem rzeczy wspomnień wojennych, wiele osób w ogóle nie chciało wspominać tamtych wydarzeń lub sami świadkowie zostali zapomniani, ponieważ w ZSRR liczyło się zwycięstwo kolektywu, państwa, ale na pewno nie jednostki. W reportażu Aleksijewicz Wojna nie ma w sobie nic z kobiety z goryczą opisuje swoje powojenne pragnienia i ich częściowe spełnienie we współczesności: ...Chcę mówić... Mówić! Wygadać się! Wreszcie ktoś chce nas wystuchać. Tyle lat milczatyśmy. Dziesiatki lat. Przez pierwszy rok, kiedy wrócitam z wojny, mówitam i mówitam. Nikt mnie nie stuchat. No więc umilktam ${ }^{47}$.

Pamięć miała być wyparta przez mit, mówienie prawdy - przez stereotypowe postrzeganie walk utrwalane nawet we współczesnych podręcznikach historii. W Federacji Rosyjskiej świętuje się zarówno 9 maja - zwycięstwo nad faszyzmem, jak i 22 czerwca - napaść Hitlera na ZSRR, czas opiewany jako Dzień Pamięci i Żalu. Trudno jednak

44 A. Miller, Polityka pamięci $w$ Rosji. Rola czynników niepaństwowych, przeł. A. Jaskólski, „Rocznik Instytutu Europy Środkowo-Wschodniej” 2015, z. 2, s. 128.

М. Немцев, Горе vs. Гордость в постпамяти, [online] http://gefter.ru/archive/18020, 4 VII 2017.

46 B. Sokołow, Prawdy i mity Wielkiej Wojny Ojczyźnianej 1941-1945, przeł. J. Stroganova, A. Sawinkow, Kraków 2015, s. 9.

47 S. Aleksijewicz, Wojna nie ma w sobie nic z kobiety, przeł. J. Czech, Wołowiec 2015, s. 84. 
zaprzeczyć, że i same święta, i związane z nimi parady, pochody, festiwale... są również częścią mitu - mitu zwycięstwa. Trudno bowiem uznać za zwycięstwo wojnę, która pochłonęła miliony istnień ludzkich. Inny kraj uznałby to zapewne za klęskę. Liczby (choć i te zmieniano i zafałszowywano) są tego najdobitniejszym przykładem: w czasach Chruszczowa i Breżniewa mówiło się o $8 \mathrm{mln}$ poległych, pod koniec istnienia ZSRR liczba ta wzrosła do $27 \mathrm{mln}^{48}$. Borys Sokołow podaje zaś oszałamiającą liczbę $43 \mathrm{mln}^{49}$. Słusznie więc Krystyna Pietrzycka-Bohosiewicz swój tekst o wojennej powieści Georgija Władimowa Generat i jego armia zatytułowała Ocalić Rosję za cenę Rosji ${ }^{50}$.

Do pierwszych zmagań wojennych przegrywanych przez Rosjan dopisuje się marksistowski mit traktowania porażek, upadków, klęsk jako cennego doświadczenia prowadzącego do zwycięstwa komunizmu ${ }^{51}$. Mit założycielski zostaje poddany ideologizacji. Mitologizacji podlega już sama nazwa wydarzenia historycznego: „Wielka Wojna Ojczyźniana" jest bowiem terminem propagandowym wygodnym dla rządzących polityków. W 1941 r. Związek Radziecki - jeszcze zanim napadli na niego Niemcy - chwiał się w posadach, a władza komunistyczna była znienawidzona przez społeczeństwo. Wojna pomiędzy III Rzeszą a ZSRR była wojną ideologiczną, wojną pomiędzy nazizmem a komunizmem. Jako pierwszy zestawienia obu systemów i wskazania na ich podobieństwa dokonał w beletrystyce Wasilij Grossman w dylogii Życie i los. Określenie zmagań bitewnych jako Wielka Wojna Ojczyźniana sprawiło, że kwestie ideologiczne przesunięto na drugi plan, a najważniejsza stała się obrona ojczyzny. Nie abstrakcyjnej ojczyzny światowego proletariatu, ale ojczyzny - matuszki Rosji ${ }^{52}$. A zatem, aby zrodził się w narodzie duch bojowy, odwołano się do tępionej bezpośrednio po rewolucji tradycji. Edward Radziński pisze, iż na początku wojny powołano organ znany jako Kwatera Główna Naczelnego Dowództwa. Stalin nazwał ją „stawką," ponieważ była to nazwa sztabu w czasach obalonego caratu. Przypadkiem nie było również przywrócenie znienawidzonych przez rewolucjonistów stopni oficerskich. Rewolucja światowa, internacjonalizm odgrywały wówczas rolę zaledwie epizodyczną. Pojawiła się idea państwa rosyjskiego - idea ojczyzny ${ }^{53}$. Stalin ogłosił więc wojnę ojczyźnianą - świętą wojnę narodu z najeźdźcą: Jak ongiś car Aleksander I po napaści Napoleona. Jak gdyby podsuwajac mu pomyst, Hitler zaatakowat tego samego dnia co Napoleon - 22 czerwca. Analogia powinna natchnąc kraj nadzieja. W 1812 roku Rosjanie też się cofali, nawet oddali Moskwę, lecz zwyciężyli ${ }^{54}$. Ten „czerwony patriotyzm” towarzyszył narodowi aż do ostatnich dni wojny.

48 T. Pawłowski, Mit „Wielkiej Wojny Ojczyźnianej”, [online] http://historia.wp.pl/title.Mit-WielkiejWojny-Ojczyznianej.wid.1, 27 III 2017, s. 2.

49 B. Sokołow, Prawdy i mity..., s. 29.

50 K. Pietrzycka-Bohosiewicz, Ocalić Rosjezza cenę Rosji... „Generat ijego armia”, [w:] tejże, Wposzukiwaniu autentyzmu. Twórczość prozatorska Gieorgija Wtadimowa, Kraków 1999, s. 103.

51 T. Pawłowski, Mit „Wielkiej Wojny Ojczyźnianej”, s. 2.

52 Tamże.

53 E. Radziński, Stalin, przeł. I. Lewandowska, M. Jagiełło, Warszawa 1996, s. 491.

54 Tamże, s. 499. 
Pseudopatriotyczny mit Wielkiej Wojny Ojczyźnianej tworzony był, zgodnie z wytycznymi władz, przez przedstawicieli kultury, w tym literatury, a w obrębie tej ostatniej zarówno w beletrystyce, jak i w sytuującym się na pograniczu literatury pięknej i literatury faktu - reportażu. Ta tendencja, zmierzająca do wcielenia w życie idei łączącej naród, odradza się obecnie. W czasie wojny twórcy zobowiązani byli wzbudzać w ludziach duch patriotyzmu, zagrzewać do zbrojnego czynu, dzisiaj zadaniem reprezentantów kultury jest akcentowanie jedności, dumy z przynależności do supermocarstwa. W ten sposób rodzi się uczucie Sojuznostalgii ${ }^{55}$. W samej sferze kultury daje się zauważyć pewna paralelność między początkiem wojny 1941 r. a czasami współczesnymi: autorzy prokremlowscy wiodą spór między ujawniającymi prawdę (na przykład film Nikity Michałkowa Spaleni stońcem 2 a liczne reportaże Aleksijewicz), tak jak w przeszłości „kaprale od literatury” (reportaże z frontu Ilji Erenburga, Wasilij Tiorkin Aleksandra Twardowskiego) stali w opozycji wobec tzw. „prawdy okopów” (Wiktor Niekrasow, nieco później Władimir Wojnowicz, Władimir Maksimow, Gieorgij Władimow...). Charakterystyczne, że głosy przedstawicieli „prawdy okopów” współbrzmią z najbardziej aktualnymi ustaleniami historyków, archiwistów i reporterów.

Jako jeden z pierwszych narodził się mit prostego radzieckiego żołnierza, idącego do walki z uśmiechem na twarzy, chętnie uczestniczącego w bojach, obdarzonego schludną, słowiańską powierzchownością, najczęściej chłopca o niebieskich oczach i jasnych, płowych włosach, wysokiego i zgrabnego, ubranego w lśniący mundur i dumnie dzierżącego w dłoniach karabin. Kłam takiemu wizerunkowi zadał m.in. Niekrasow w powieści $W$ okopach Stalingradu. Opisał tu szczegółowo dzień powszedni szeregowców, dając obraz pozbawiony sakralizacji i odświętności wojennych zmagań. Codzienność żołnierza, według Niekrasowa, to głód, zimno, brak odpowiedniego ubrania, tęsknota za domem... ${ }^{56}$ Taki wizerunek był nie do przyjęcia, dlatego książka szybko znalazła się na indeksie. W formie jeszcze silniej przemawiającej do odbiorcy, bo z zastosowaniem satyry i groteski, zaprezentuje szeregowego uczestnika wojny Władimir Wojnowicz, łamiąc tym samym nie tylko nakazy ideologii, ale i wytyczne ,jedynie słusznej metody" - socrealizmu, w obrębie której bohater pozytywny był jednym z najważniejszych komponentów. Narrator w sposób prześmiewczy i prowokacyjny zwróci się do odbiorcy: Drogi czytelniku! Zauważyteś już, oczywiście, że żotnierz ostatniego roku stużby Iwan Czonkin byt maleńkiego wzrostu, nogi miat krzywe, a do tego jeszcze czerwone uszy. „Co za niewydarzona figura! - powiesz z oburzeniem. - Gdzie tu przyktad dla mtodego pokolenia? I gdzie autor widziat takiego - wstyd powiedzieć - bohatera?" A ja, autor, przyciśnięty do muru i schwytany zaiste na goracym uczynku, będę musiat przyznać, $\dot{z} e$ nigdy go nie widziatem, że go wymyślitem i wcale nie dla przyktadu, tylko tak sobie, z nudów. „Zatóżmy, że tak wtaśnie byto - powiesz czytelniku nieufnie - ale w takim razie, po co go wymyślać? Czy autor nie mógt wziać z życia prawdziwego żotnierza-chwata,

55 J. Olędzka, Rola pamięci o Wielkiej Wojnie Ojczyźnianej w strategii utrwalania jedności narodu rosyjskiego, „Studia Podlaskie” 2016, t. 24, s. 138.

56 Zob. więcej: L. Suchanek, Mur. O zapiskach Wiktora Niekrasowa, [w:] Emigracja i tamizdat. Szkice o wspótczesnej prozie rosyjskiej, red. tenże, Kraków 1993, s. 267-285. 
wysokiego, zgrabnego, karnego, przodownika wyszkolenia bojowego i politycznego?” Mógtbym, rzecz jasna, ale nie zdażytem. Wszyscy przodownicy zostali rozchwytani i mnie zostat tylko Czonkin' ${ }^{\text {'7 }}$. Czonkin - czerwonoarmista - staje się pretekstem do prezentacji funkcjonowania armii radzieckiej ${ }^{58}$. Pilnowanie nieprzydatnego, zdezelowanego samolotu wskazuje na brak dostatecznego wyposażenia bojowego wojska, niedostatki amunicji, głodowe racje żywnościowe... Jest to dziwne choćby ze względu na fakt, że Związek Radziecki nastawiony był przede wszystkim na dbałość o przemysł zbrojeniowy. Borys Sokołow przełamuje ten mit, twierdząc, że Armia Czerwona nie była bardziej profesjonalna i nie walczyła lepiej nie tylko na początku, ale nawet w drugiej połowie wojny ${ }^{59}$. Badacz dokonuje w ten sposób demitologizacji dwóch kolejnych stereotypowych kwestii: pierwsza to teza, że anglo-amerykańska pomoc w ramach Lend-Lease Act miała dla zwycięstwa na wschodzie znaczenie marginalne, druga, że marginalne było znaczenie otwarcia drugiego frontu i wkładu zbrojnego aliantów. Do dziś w Rosji panuje przekonanie, że to Armia Czerwona zmiażdżyła Wehrmacht i że pokonataby go tak czy inaczej $j^{60}$. Dzieje się tak dlatego, że w Związku Radzieckim zawyżano poziom produkcji własnej. Dane o sukcesach radzieckiej ekonomiki wojennej, które miały przyczynić się do ostatecznego zwycięstwa, przez dziesięciolecia były argumentem propagandowym dowodzącym przewagi socjalizmu nad kapitalizmem. Ponadto mit obalają inne dane dotyczące towarów (konserwy, benzyna lotnicza...), które łatwo przemilczeć, ponieważ nie jest to bron' ${ }^{61}$. Jaką broń zatem wykorzystywano do walki? Początkowo, choć trudno w to uwierzyć, były to noże, saperki, w następnej kolejności - granaty i strzelby odbierane poległym Niemcom. Żołnierze radzieccy nie znali nawet taktyki walki, strategii potyczek wojennych. Dlatego tak często w filmach fabularnych, ale nawet dokumentalnych, przedstawia się ich, jak biegną do walki wyprostowani, widoczni z daleka, stanowiący latwy obiekt dla wroga. Mimo trwania w stanie permanentnej wojny nikt nie nauczył ich rzemiosła wojennego. Wielki Terror przyczynił się do tego, iż w łagrach osadzeni zostali najlepsi oficerowie. Ci, którzy pozostali przy życiu, byli spętani strachem, bali się podejmować decyzje bądź byli zaledwie „dowódcami gabinetowymi", nieraz nawet niezdającymi sobie sprawy, w którym kierunku przesuwa się front. Taki groteskowy obraz radzieckich przywódców podczas równie groteskowej „narady” w Spaso-Pieskowskim ukazał Georgij Władimow w powieści Generat i jego armia ${ }^{62}$. W tym utworze pojawił się również, nie do przyjęcia dla radzieckiego „patrioty” i niezgodny z oficjalną ideologią, pozytywnie nakreślony wizerunek

57 W. Wojnowicz, Życie i niezwykte przygody żotnierza Iwana Czonkina, przeł. W. Dłuski, Chotomów 1990, s. 19-20.

58 A. Dudek, Groteska jako próba realizmu. O książce Wtadimira Wojnowicza „Życie i niezwykte przygody żotnierza Iwana Czonkina", [w:] Emigracja i tamizdat..., s. 225-249.

59 B. Sokołow, Wielka wojna mitów, czyli jak ZSRR ukrywato prawdę o II wojnie światowej, „Newsweek” 2014, 21 VI, s. 11.

60 Wielka wojna mitów, czyli jak ZSRR ukrywato prawdę o II wojnie światowej, wywiad I.T. Miecika z B. Sokołowem, „Newsweek Historia” 2013, nr 12, s. 4.

61 Tamże.

62 K. Pietrzycka-Bohosiewicz, Ocalić Rosję za cenę Rosji..., s. 107-112. 
świetnego niemieckiego stratega Heinza Guderiana, mającego odwagę sprzeciwić się rozkazom płynącym ze sztabu generalnego, aby tylko ratować swoich żołnierzy. Guderian rozmyśla także nad zagadką duszy rosyjskiej, zastanawiając się, co zagrzewało prostych Rosjan, zgnębionych przez system, głodnych, pozbawionych ciepłego odzienia, do tak heroicznej walki. Wnioski okazały się kuriozalne: to właśnie niewyobrażalne wręcz w normalnych warunkach przyzwyczajenie do braku pożywienia, do mrozu... zagrzewało do walki w ekstremalnych warunkach. Tak naszkicowany obraz niemieckiego generała (który w świadomości statystycznego Rosjanina musiał być jednoznacznie zły) wywołał falę ostrej krytyki wobec powieści i jej autora.

Jak wynika z powyższego, pisarze undergroundowi zburzyli mit o zwycięstwie wojny przez najwyższe dowództwo, przypisując je prostemu żołnierzowi. Tak właśnie jest w przypadku bohatera powieści Władimira Maksimowa Siedem dni tworzenia. Jeden z jej bohaterów - Andriej Łaszkow - człowiek rozdarty wewnętrznie i pełen przeciwieństw obarczony zostaje podczas II wojny światowej absurdalnym obowiązkiem ewakuacji bydła ${ }^{63}$. W tej części Maksimowowskiej powieści wyraźne są znamiona czasu: sztucznie pobudzony patriotyzm, żołnierze rzucani jako mięso armatnie, dobrowolne przejścia na stronę Niemców, nieustające fale aresztowań. Dopiero podczas wojny, jak słusznie zauważa Martin Malia, reżim i naród mieli wspólne zadanie i cel: Do tego czasu reżim robit cośludności, teraz ludność i reżim robili cośrazem. Pamiętajmy jednak, $\dot{z}$ e ta nowa legitymacja będzie tracita ważność w miare odchodzenia wojny w przesztość. Mimo to jednak więź przez nia wytworzona data reżimowi dodatkowych czterdzieści pięć lat życia, czego prawdopodobnie zalety samego systemu nie mogtyby zapewnic ${ }^{164} . \mathrm{Z}$ drugiej strony, o czym napomknięto już powyżej, a co mocno akcentuje Maksimow, prości żołnierze stali się ofiarami tej wojny. Na początku zmagań wojennych Stalin wydaje bezsensowny rozkaz stałej ofensywy, bez względu na okoliczności, a zamknięte to zostało w lapidarnym haśle-sloganie „ani kroku wstecz”. Niemcy atakowały ZSRR w bardzo szybkim tempie, stąd absurdalność tego zarządzenia. Oddziały radzieckie znajdowały się w stałym okrążeniu, żołnierze masowo brani byli do niewoli, później, jako tzw. „okrużeńcy” trafiali do łagrów, czego najbardziej dobitnym przykładem beletrystycznym jest tytułowa postać utworu Sołżenicyna Jeden dzień I wan a Denisowicza: Szuchowowi udało się uciec z okrążenia niemieckiego i przedostać się do „swoich”. Ci ostatni jednakże nie okazywali radości w takich przypadkach: powszechnie uważano, iż „okrużeniec" zdradził tajemnice wojskowe, dlatego pozwolono mu przełamać okrążenie, gdyby nie zdradził - zostałby z pewnością rozstrzelany. Po raz kolejny zatem spotykamy się tutaj z antylogiką mitu radzieckiego, nakazującego widzieć wroga w każdym, kto tylko zetkną się z reprezentantem przeciwnej linii frontu.

A zatem wojsko, tak samo jak wszystkie dziedziny życia w Związku Radzieckim, podlegało centralizacji. Niejednokrotnie żołnierze nie odczuwali strachu przed wzięciem do niewoli, gdyż uważali Niemców za bardziej cywilizowanych. W końcu i tych, którzy nie mieli motywacji do walki, i tych, którzy walczyli mężnie, ale mimo wszystko

63 Zob. K. Duda, Wiara i naród. Twórczość Wtadimira Maksimowa, Kraków 2001, s. 39-147.

64

M. Malia, Sowiecka tragedia..., s. 310. 
trafili do niewoli, uważano za zdrajców i dezerterów i zazwyczaj podlegali oni egzekucjom. Często rzucano pod ich adresem oskarżenia: - Jesteś zdrajca! Ratowateśswoją skórę, a nie ojczyznę (Czasy secondhand..., s. 51). Niełatwo żyło się dzieciom takich „zdrajców" już po wojnie. Nie mogły zajmować odpowiedzialnych stanowisk, nie pozwolono im wstępować na wyższe uczelnie: Tak się dowiedziatam, że my..., że wszyscy, którzyśmy żyli pod okupacja, jesteśmy... niepewny element. Podejrzany (Czasy secondhand..., s. 94). W ten sposób pękał mit bohaterszczyzny, integralnie wpisany w rosyjską świadomość, mit, którym karmiono Rosjan i dzięki któremu mogli czuć się dumni, wyjątkowi: Rosjanin musi w coś wierzyć... Wierzyć w cośświetlanego, wzniostego. Wnaszej podświadomości tkwia imperium i komunizm. Blizssze jest nam to, co bohaterskie (Czasy secondhand..., s. 41).

Jeśli chodzi o podjęty m.in. przez Maksimowa problem dobrowolnego przechodzenia na stronę okupanta, to sprawa ta związana była w większości z ludnością cywilną. Cywile witali niejednokrotnie Niemców jako wybawicieli spod jarzma bolszewickiego. Żywiono nadzieje (złudne, jak się miało okazać) na rezygnację z kołchozowego gospodarowania, otwarcie świątyń, a nawet wyzwolenie narodowe. Richard Overy wyróżnia w związku z tym kilka kategorii „kolaborantów”: 1) Jedni przechodzili na stronę wroga bezinteresownie, a powodowała nimi nienawiść wobec radzieckiego komunizmu. 2) Drudzy wierzyli, że Niemcy przywrócą prywatną własność ziemską i kapitalistyczną przedsiębiorczość. 3) Inni współpracowali z Niemcami, ponieważ dostrzegali w tym możliwość ustanowienia niezależnych państw ${ }^{65}$.

Stereotypowe, lansowane przez oficjalną propagandę stwierdzenie, iż w okresie walk pustoszeją łagry, znów balansuje między mitem a jawną nieprawdą. Niektórzy $W$ latach czterdziestych z piekta trafili do piekta (Czasy secondhand..., s. 11). W czasie wojny trwają aresztowania i zapełniają się łagry. Aresztowaniu podlegają w pierwszej kolejności realni i wyimaginowani kolaboranci. Rosjanie, którzy dostali się do niewoli niemieckiej, ale również deportowani masowo obywatele mniejszości narodowych i mieszkańcy zagarniętych terytoriów. Paradoksalnie: w okresie zmagań wojennych więźniowie obozów woleli często uczestniczyć w bojach frontowych, niż przeżywać piekło obozu. Ten fakt dobrze ilustruje cytat z Doktora Żywago Borysa Pasternaka: Kto zgtosi się jako ochotnik do karnego batalionu $i z$ niekończących się bojów wyjdzie cato - będzie wolny. I potem natarcia, natarcia, kilometry drutów kolczastych z elektrycznym pradem, miny, miotacze min i miesiace, miesiace huraganowego ognia. Nie darmo nazywano nas straceńcami. Śmierć kosita nas do ostatniego. Jak ja wyżytem? Ale wyobraź sobie, że cate to krwawe piekto byto niezmacconym szczesściem w porównaniu z okropnościami obozu koncentracyjnego i bynajmniej nie z powodu ciężkich warunków, ale z zupetnie innej przyczyny. Dziwna rzecz. Nie tylko dla siedzacych w twoim obozie, ale dla wszystkich żyjacych w trzydziestych latach, nawet na wolności, nawet w pomyślnych warunkach pracy uniwersyteckiej, wśród książek, wygód i pieniędzy, wojna byta burzq oczyszczającq atmosferę [podkreślenie - K.D.], powiewem świeżego powietrza, zapowiedzia wyzwolenia ${ }^{66}$. Dla ogromnej

65 R. Overy, Krew na śniegu. Rosja w II wojnie światowej, przeł. M. i T. Luftnerowie, Gdańsk 1999, s. 182.

66 B. Pasternak, Doktor Żywago, przeł. D. Chróścielewska, Warszawa 1990, s. 460. 
ilości zeków udział w wojnie z Hitlerem był prawdziwym przywilejem. Wojna mogła być bowiem pewną perspektywą na przyszłośćc ${ }^{6}$. A że tak się nie stało, że naród sam dopomógł w kolejnym zakuciu się w kajdany - świadczą dalsze lata istnienia systemu.

Kolejnym mitem przełamywanym zarówno przez historyków, jak i beletrystów był mit radzieckiego partyzanta-bohatera, dobrowolnie poświęcającego się dla dobra ojczyzny. Trudno jednak byłoby zestawić polski partyzancki ruch oporu, działania „leśnych chłopców” z, niejednokrotnie wymuszoną, aktywnością partyzantki w ZSRR. Przyznać należy, że ruch partyzancki w Rosji miał długą tradycję. Dość wspomnieć walki oddziałów partyzanckich w okresie wojny napoleońskiej 1812 r., opowiedzenie się partyzantów po stronie bolszewików i zwalczanie przez nich kontrrewolucjonistów podczas wojny domowej. W latach $30 . \mathrm{XX}$ w. Stalin, obawiając się partyzantów działających w rozproszeniu, niepodlegających Centrum, rozkazał zlikwidować ich dowódców. Wszystko to sprawiło, że na początku Wielkiej Wojny Ojczyźnianej ruch partyzancki był nieskoordynowany, funkcjonował spontanicznie i nieporadnie. W tej sytuacji Stalin zaczął rozpowszechniać kopię artykułu Lenina z 1906 r. zatytułowanego Wojna partyzancka. Artykuł, z którym musieli się zapoznać partyzanci, w dużej mierze opierał się na zasadach terroryzmu. Wszyscy mieli składać przysięgę, dotyczącą bezwzględnej lojalności wobec ZSRR, priorytetowego traktowania walk i powinności wobec ojczyzny. Zgodnie z tą przysięgą w razie konieczności należało poświęcić własną rodzinę, natomiast łamiący przysięgę był rozstrzeliwa$n y^{68}$. Christian Hartmann dodaje: Ruch oporu na okupowanych obszarach radzieckich byt [...] bardziej zróżnicowany, niż próbowata to później przedstawiać historiografia radziecka. Poza "czerwonymi” istniaty grupy polskie, ukrainskie, battyckie, żydowskie $i$ wreszcie takie, które tylko chciaty przeżyć w konspiracji. To, że cztonkowie tych grup czessto się nienawidzili, nie upraszczato sytuacji ${ }^{69}$. Jeśli dodać do tego, że Niemcy za jednego zabitego rodaka rozstrzeliwali 50-100 partyzantów, to sytuacja tych ostatnich staje się dramatyczna. Pogłębia ją jeszcze fakt braku broni, głodu powodującego przymus spożywana mchu i kory drzewnej, siarczyste mrozy, otoczenie, w którym działali: gęste lasy, bagna... To prawda, że udało im się przeprowadzić wiele spektakularnych akcji dywersyjnych: niszczenie torów kolejowych, wysadzanie mostów. Przełamywanie mitu o ich heroizmie następuje, gdy zwrócimy uwagę na stosunek partyzantów do ludności cywilnej. Do partyzantki siłą wcielano kobiety, dzieci, a nawet niedołężnych starców. Co więcej, partyzanci traktowali rosyjską ludność cywilną równie okrutnie i bezlitośnie jak Niemców. Jedna z interlokutorek Aleksijewicz wyzna: Kiedy Niemcy się wycofywali, to zabrali nam świniaka, wytapali ostatnie kury. A przedtem partyzanci noca zabrali krowe... Krowy mama nie chciata oddać, to jeden $z$ nich strzelit w górę. W dach. Wtożyli do worka i maszynę do szycia, i sukienki mamy. Partyzanci to byli czy bandyci? (Czasy secondhand..., s. 67).

67 F. Furet, Przesztość pewnego ztudzenia. Esej o idei komunistycznej w XX wieku, przeł. J. Górnicka-Kalinowska, M. Ochab, Warszawa 1996, s. 423.

68 Zob. więcej: R. Overy, Krew na śniegu..., s. 203-215.

69

Ch. Hartmann, Wielka Wojna Ojczyźniana 1941-1945, przeł. B. Ostrowska, Poznań 2014, s. 131. 
Dorota Pazio-Wlazłowska słusznie zauważa, iż oficjalny mit nie pozwala nie tylko na oddanie czci heroicznej, bohaterskiej ofierze społeczeństwa, ale również umożliwia zepchnięcie na drugi plan tego wymiaru wojny, który powinien zostać przemilczany ${ }^{70}$. Sakralizacji podlegają w związku z tym uroczyste, podniosłe strony wojny i czasów powojennych: defilady, akademie, przemówienia, pokazy sztucznych ogni w dniach kolejnych rocznic zwycięstwa nad faszyzmem. Starsi, schorowani ludzie przywożeni są do centrum Moskwy specjalnymi autokarami po to, by zaświadczyć o sile państwa radzieckiego, o mocarstwowości dzisiejszej Federacji Rosyjskiej. Ubrani w mundury ozdobione lśniącymi odznaczeniami i orderami mają stanowić symbol siły i potęgi. Jest to jednak kolejna w historii Rosji sztuczna atrapa, wioska potiomkinowska, widowisko na pokaz, z udziałem ,aktorów epizodycznych”, ale za to z pominięciem prawdziwych bohaterów tamtych dni, zapominając, iż Zwyciężyta umęczona, chora armia. Wycieńczona, kaszlaca. Cierpiąca na korzonki, na zapalenie stawów... chorująca na żotądek (Czasy secondhand..., s. 131). Aleksijewicz przytacza w swoim reportażu przypadek 77-letniego frontowca Timeriana Zinatowa, bohaterskiego obrońcy twierdzy w Brześciu. W pierwszych dniach obrony twierdzy został ranny. Trafił do niewoli. Udało mu się uciec z obozu koncentracyjnego. Zakończył wojnę jako szeregowiec. Za obronę Brześcia otrzymał Order Wojny Ojczyźnianej II stopnia. Po wojnie przemierzył niemal cały kraj: pracował na budowach Dalekiej Północy, budował Magistralę Bajkalsko-Amurską, już jako emeryt pozostał na Syberii. Był więc wiernym i prawdziwym synem swojej ojczyzny zarówno w czasie wojny, jak i pokoju. Corocznym rytuałem, patriotycznym obowiązkiem i prawdziwym świętem stało się dla niego przemierzanie tysięcy kilometrów i przyjazd do Brześcia, do muzeum. Tylko w twierdzy czuł się bezpiecznie, tak samo jak jego koledzy z wojska, z którymi się tu spotykał. Dodajmy: tutaj, w miejscu, w którym mógł zostać zabity, czuł się potrzebny i niezastąpiony. Takie pragnienia, z punktu widzenia psychologii, ma każdy człowiek, nawet w czasie pokoju, kiedy odżywają wspomnienia, a dookolna rzeczywistość nie sprzyja okazywaniu szacunku prawdziwym zwycięzcom. Po raz ostatni Zinatow przyjechał do Brześcia już po upadku Związku Radzieckiego, w 1992 r. Tuż po jego domniemanym wyjeździe prokuratura podała do publicznej wiadomości, że obrońca twierdzy brzeskiej, który przeżył walki w krwawym kotle 1941 r., popełnił samobójstwo, rzucając się pod rozpędzony pociąg. Znaleziono przy nim pieniądze, które przywiózł na własny pogrzeb. Duma nie pozwalała mu na państwowy pochówek, zwłaszcza na pogrzeb zorganizowany przez państwo, które, w jego mniemaniu, zaprzedało szczytne cele i ideały. Wolał umrzeć, zamiast żebrać o nędzny, państwowy zasiłek (Czasy secondhand..., s. 204-208). W zbiorze reportaży Czasy secondhand. Koniec czerwonego cztowieka znajdziemy też wspomnienia innych weteranów, których docenia się tylko raz w roku, w Dniu Zwycięstwa, wygłaszając na ich cześć obłudne mowy pochwalne. Przez resztę roku stają się niepotrzebni, deformują krajobraz modnych restauracji i galerii handlowych: Niedawno obaj z przyjacielem (to byty putkownik i też weteran wojenny) przyjechali do Moskwy. Wtożyli z tej okazji odświętne

70 D. Pazio-Wlazłowska, Pamięć Wielkiej Wojny Ojczyźnianej w narracjach mtodzieży, „Politeja” 2015, nr 3 (35), s. 272. 
garnitury z baretkami orderów. [...] byli zmęczeni [...], chcieli posiedzieć, zanim nadjedzie pociag. Wolnych miejsc zabrakto, więc weszli do pustawej sali, gdzie byty fotele i bufet. Od razu podbiegta do nich dziewczyna, która roznosita po sali napoje, i ordynarnie pokazata im drzwi: "Panom tu nie wolno, tu jest sala dla biznesu” (Czasy secondhand..., s. 204). A zatem nawet mit weterana został zniekształcony, wykrzywiony. W jego obrazie funkcjonuje pamięć przefiltrowana, punktowa zaledwie, wybierająca to, co w danej chwili przydatne i potrzebne. To, co nie pasuje do pochodów i parad, pogrąża się w otchłani niepamięci. Najjaskrawszym tego dowodem jest przywołany przez Pazio-Wlazłowską, a zamieszczony w periodyku „Moskowskij Komsomolec” artykuł A. Dobrowolskiego pod znamiennym tytułem "Samowary” towarzysza Stalina. Okazuje się, że w latach 1950-1984 w monastyrze na Wałaamie działał ośrodek dla inwalidów wojennych, których, ze względu na brak rąk i nóg, nazwano „samowarami” ${ }^{1}$. Kalecy obrońcy ojczyzny, żebrzący na ulicach i dworcach, proszący o jałmużnę psuli odświętny, powojenny krajobraz, przypominając o klęskach i porażkach. Na Wałaamie umieszczono inwalidów w nieogrzewanych pomieszczeniach, pozbawionych łaźni, stołówki, opieki medycznej. Odebrano im dowody osobiste i książeczki wojskowe. Monastyr przypominał obóz bądź więzienie ${ }^{72}$.

Pisząc o mitologii radzieckiej, trudno pominąć postać, która w największym, niewyobrażalnym wręcz stopniu uległa mitologizacji. To, oczywiście, postać Stalina - cara, boga, ojczulka, który stał się architektem zwycięstwa II wojny światowej i również swemu narodowi wszczepił świadomość zwycięzcy. A czystki, Wielki Terror, GUŁag? To nie Wielki Wódz jest temu winien. Przez cały okres terroru NKWD rozpowszechniał mit, że Stalin nic nie wie o „nocnym życiu”, o aresztowaniach, rewizjach, zabójstwach... ${ }^{73}$ Po początkowym, krótkotrwałym zwątpieniu wywołanym porażkami w pierwszych bitwach Stalin odzyskuje dawny wigor. Skoro jest bogiem - jest wszystkim: [...] tworzy

71 D. Pazio-Wlazłowska, «Памsть, Дама 3абыьчивая» - Wielka Wojna Ojczyźniana: od mitologizacji do niepamięci, „Porównania” 2012, nr 11, s. 70.

72 Odwrotną stroną tej kwestii są tzw. mity ofiarne, dotyczące ludzi, którzy jakoby poświęcali własne życie, torowali szlak bojowy, w sposób wręcz magiczny pokonując wroga. Należą do nich m.in. mity o 28 gwardzistach panfiłowcach, marynarzach z Sewastopola oraz żołnierzu Matrosowie. Groźne jest to, że mimo iż stanowią historie nieprawdziwe bądź przesadzone, nadal znajdują się w obowiązkowym kanonie lektur na lekcjach literatury i historii w Federacji Rosyjskiej. Demitologizacji tych fałszywych kombatantów dokonał m.in. B. Sokołow, stwierdzając na przykład (poprzez wykorzystanie dokumentów), że jeden z panfiłowców był kolaborantem, wiernie służącym Niemcom, natomiast pięciu marynarzy z Sewastopola, pod wodzą politruka, jesienią 1941 r. rzuciło się na niemieckie czołgi z wiązką granatów i zniszczyło 15 maszyn. Pomijając graniczący z cudem fakt zniszczenia tak dużej liczby pojazdów opancerzonych przez garstkę samobójców, należy dodać, że mit ten upada w konfrontacji z dokumentalnymi zapisami świadczącymi, że siły rumuńsko-niemieckie, oblegające w październiku 1941 r. Sewastopol, nie miały ani jednego czołgu. Więcej: nie posiadały nawet artyleryjskich ciągników mechanicznych, jedynie tabor koński. Matrosow natomiast stał się mitycznym herosem, ponieważ zasłonił własną piersią gniazdo cekaemu. W rzeczywistości ten, będący pod wpływem alkoholu, żołnierz padł martwy na otwór wentylacyjny i niemiecka załoga przerwała ogień, próbując usunąć zwłoki. Ten moment wykorzystali pozostali szturmujący i podeszli tak blisko, że Niemcy musieli uciekać. Zob. B. Sokołow, Prawdy i mity..., s. 389-429.

73 E. Radziński, Stalin, s. 448. 
Państwowy Komitet Obrony, majacy petna wtadze w kraju. Sam staje na jego czele. Po dziesięciu dniach mianuje się naczelnikiem Kwatery Gtównej. Wkrótce jest już naczelnym dowódca, przewodniczacym Komitetu Obrony, ludowym komisarzem obrony, przewodniczącym Rady Ministrów i wodzem partii ${ }^{74}$.

Wiara ludu w Wielkiego Sternika tylko z lekka zachwieje się podczas chruszczowowskiej odwilży, załamie się silniej w latach pierestrojki, by znów współcześnie przybrać na sile. Świadczy o tym choćby utwór Wojnowicza Spiżowa mitość Agtai. Zamysł powieści zrodził się już w latach 70. XX w., ale wypierany był przez inne projekty twórcze, a później, zdaniem autora (błędnym, jak się okazało), utracił aktualność. Pomysł ukończenia utworu pojawił się ponownie w połowie lat 90., kiedy okazało się, że w poszukiwaniu tzw. „idei rosyjskiej” ludzie znów zwracają się ku przeszłości, z nostalgią wspominając Związek Radziecki ${ }^{75}$. Wizja Wojnowicza okazała się prorocza, skoro w napisanym w roku 2009 reportażu Czasy secondhand... na jednej z pierwszych stron znajdujemy następujący fragment: W spoteczeństwie pojawito się zapotrzebowanie na Zwiazek Radziecki. Na kult Stalina. Potowa mtodych ludzi między dziewiętnastym a trzydziestym rokiem życia uważa Stalina za „największego polityka”. Nowy kult Stalina w kraju, w którym wymordowat on nie mniej ludzi niz Hitler? Znowu w modzie jest wszystko, co radzieckie... (Czasy secondhand..., s. 15). Urywek ten wpisuje się zatem organicznie w wymowę ideową Spiżowej mitości Agtai Wojnowicza, w której znów odżywają mity, radziecka mitologia i próba demitologizacji zakłamanych faktów. W trakcie pisania powieści wydawało się, iż wiele jej fragmentów przybrało charakter groteskowo-retrospektywny, jednak już po transformacji ustrojowej te na pozór „archaiczne” problemy znów znalazły się w sferze absolutnie realnej praktyki politycznej. W powieści Wojnowicza, chroniony i broniony przez główną bohaterkę - Agłaję Stiepanownę Riewkinę, pomnik Stalina, staje się osią kompozycyjną utworu i spoiwem scalającym wydarzenia. Wprowadzenie symbolu pomnika okazało się zabiegiem niezwykle owocnym w znaczenia i alegoryczne odczytanie struktur zmitologizowanej rzeczywistości. Wymowny, albowiem także poddany mitologizacji, jest opis samego monumentu: Stalin byt $w$ petnej gali, z naramiennikami generalissimusa, $w$ lekko rozpiętym szynelu, by widać byto mundur i ordery, z uniesiona prawa ręka, zapewne po to, by pozdrawiać defilujace przed nim masy. W lewej, opuszczonej, trzymat rękawiczki. Spogladat na zebranych jak żywy. Patrzyt z góry w dót z tajemniczym uśmiechem pod wasem i jak się wszystkim zdawato, machat wyraźnie prawa ręka, lewa uderzając rękawiczkami po kolanie $e^{76}$.

Pełna uwielbienia dla Stalina jest główna bohaterka Wojnowiczowskiej powieści Agłaja Riewkina: po obaleniu kultu jednostki i jednocześnie usunięciu z cokołu pomnika Wodza, umieszcza żeliwny monument w swym mieszkaniu i opiekuje się nim jak żywą istotą. W zachowaniu Agłai jest tyleż mistycyzmu, co erotyzmu. Heller pisał, że erotyczne uwielbienie Wodza było nieodłącznie związane z kultem Stalina ${ }^{77}$. Pustkę

Tamże, s. 501.

75 Zob. K. Duda, Socrealistyczna propaganda i postkomunistyczna pustka aksjologiczna (Wtadimir Wojnowicz: „Spiżowa mitość Agtai”), „Slavia Orientalis” 2008, nr 1, s. 83-95.

76 W. Wojnowicz, Spiżowa mitość Agtai, przeł. H. Broniatowska, Warszawa 2006, s. 14.

77 M. Heller, Maszyna iśrubki..., s. 53. 
po Bogu Stwórcy wypełniła cześć dla ziemskiego bożka, dla idola. W tym przypadku utwory beletrystyczne odzwierciedlają rzeczywistość. I tak na przykład gigantyczny posąg Stalina stał na kanale Wołga-Don, kolejnym, który zbudowali więźniowie. To, co się wydarzyło z tym pomnikiem, wygląda jak zabawna metafora epoki. Przykład na bałwochwalcze traktowanie Iosifa Dżugaszwilego przytacza Edward Radziński: Pewnego razu stróż, pilnujacy rzeźby, z przerażeniem zauważyt, że ptaki w czasie przelotów odpoczywaja na gtowie posagu. Nietrudno wyobrazić sobie, czym to grozito jego twarzy. Ale ptaków nie sposób ukarać. Za to ludzi oczywiście można. I śmiertelnie przerażone kierownictwo obwodu znalazto wyjście - do gigantycznej gtowy podtaczono prad wysokiego napięcia. I teraz posag stat otoczony dywanem $z$ martwych ptaków ${ }^{78}$. Dodajmy, iż w praktyce tak pojmowana mitologizacja oznacza postawę zamknięcia się na drugiego człowieka, obojętności wobec zła. Na mocy takiej postawy Riewkina zaniedbała proces wychowania swego syna, a w rezultacie doprowadziła do zerwania z nim więzi. Przywiązanie do martwego herosa okazało się silniejsze od przywiązania i miłości do własnego dziecka.

Spiżowa mitość Agtai, w zarysowanym powyżej kontekście, wydawać by się mogła trafną diagnozą rzeczywistości totalitarnej. Byłoby to jednak uproszczenie problemu, albowiem przejawy mitologizacji połączonej z elementami idolatrii można obserwować współcześnie. Jaskrawym tego przykładem była, nagłaśniana przez media, historia pomnika żołnierza radzieckiego w Tallinie i jego usunięcia z zajmowanego dotychczas miejsca. Sytuacja ta przybrała formę otwartego konfliktu politycznego.

Kiedy Wojnowicz kończył pisać swą powieść pod koniec lat 90., idea obrony pomnika Stalina sprawiała wrażenie absurdalnej. Okazało się jednak, że jest ona niezwykle żywotna. Już po ukończeniu książki można było obserwować przywracanie pomników na ich dawne miejsce oraz powstawanie wielu nowych. Agłaja nie jest więc przypadkiem odosobnionym. Zdaniem Wojnowicza, relacje Rosjan z pomnikami od dawna układają się w znany schemat „burzyć i budować”. Poprzez pogardę dla posągów naród wyraża swe pretensje i nienawiść do władzy. Tak było i po zrywie październikowym $1917 \mathrm{r}$. i po wydarzeniach sierpniowych 1991 r.: Powiedzieć komuś w sierpniu 1991 roku, że we wrześniu 2004 pod Moskwa zostanie w uroczystej atmosferze odstonięty pomnik Feliksa Dzierżyńskiego (niemal kopia tego, który stat na Eubiance) - nikt by nie uwierzyt. Ale to fakt. W tym samym czasie nikt również nie pomyślat i o tym, że wkrótce po odstonięciu „brązowego Feliksa” w miasteczku Dzierżyńsk na drugim końcu kraju, w Irkucku, zacznie się montaż miedzianego postumentu „krwawego kata” - Kotczaka ${ }^{79}$. Z kolei w Iszymie, w listopadzie 2003 r., na placu Wielkiego Października postawiono pomnik Stalina. Warto przedstawić krótkie dzieje iszymskiego postumentu: na początku lat 60. popiersie z brązu stało na jednym z miejskich skwerów, w okresie zwalczania kultu jednostki zostało zdemontowane. Przez pewien czas popiersie znajdowało się w rejonowym komitecie partii. W 1999 r. trafiło do muzeum, zajmując miejsce w ekspozycji „Historia miasta w okresie radzieckim", niedługo potem przedstawiciele partii komunistycznej

E. Radziński, Stalin, s. 10.

79 Монумкнтальная контрпропаганда, s. 2, [online] https://newizv.ru/news/society/14-09-2004/ 11319-monumentalnaja-kontrpropaganda, 21 VI 2002. 
i weterani II wojny światowej wysunęli propozycję postawienia pomnika w centrum miasta. Jeden z argumentów był taki, że do muzeum nie można przynosić kwiatów, które były wyrazem wdzięczności dla Wodza ${ }^{80}$. W ten oto sposób znaleziono „odpowiednie” miejsca: dla jednych - „święte”, dla drugich - „historyczne”.

Tymczasem w końcowym akapicie powieści Wojnowicza przenosimy się w czasy współczesne, kiedy to narrator po raz kolejny uwidacznia swą obecność, obserwując krajobraz miasta Dołgowa: Piedestat byt jeszcze widoczny. Dolna częśc tonęta we mgle i dlatego góra wydawata się oderwana od ziemi, unoszaca się nad nią, a ze zagęszczeń mgty i być może z mojej rozhuśtanej wyobraźni uksztattowata się figura. Cośna podobieństwo cztowieka. Patrzyt w ślad za mna i z uśmiechem machat lekko uniesionq w góręprawa rękq ${ }^{81}$. Niektórzy skłonni się byli dopatrywać tutaj postaci prezydenta - Władimira Putina ${ }^{82}$. Wydaje się, że fragment ów ma bardziej uniwersalną wymowę. Otóż komunizm dobiegł końca jedynie w sposób formalny. W istocie jednak trwa nadal w świadomości, w umysłach ludzi, wciąż podlegając mitologizacji. I musi minąć co najmniej kilkadziesiąt lat, aby utopijny ustrój zatarł swe kontury, albo - i to jest opcja, której boją się antyutopiści - pojawi się kolejny tyran zniewalający ludzi.

W Spiżowej mitości Agtai nie zabrakło również odniesień do Wielkiej Wojny Ojczyźnianej, która nadal napawa dumą mieszkańców ZSRR i którą wykorzystano w walce ideologicznej o „świetlaną przyszłość”: Ruch „Za siebie i za tamtego chtopca” zrodzit się w tym czasie, gdy ludzie poczuli się trochę zmęczeni powszechna budowa komunizmu ispodziewali się jakiejś materialnej zachęty. Ale zamiast pieniędzy i lepszego życia wynajdywano im nowe, szczytne ideaty i podsuwano patriotyczne idee. Uzbrojony ideowo naród na wezwanie partii i komsomotu lub z wyroku sadowego wycinat tajge, kopat kanaty, uprawiat ugory, budowat Bajkalsko-Amurska Magistrale... ${ }^{83}$

Groteskową personifikacją II wojny światowej, jej żywą legendą stał się w utworze Wojnowicza Fiodor Fiodorowicz Szmirusow - kombatant odcinający kupony od swej wojennej chwały, którą zdobył kosztem ofiary poniesionej przez jego towarzysza broni - Sieriożę Żukowa. Paradoksalnie: rodzina Żukowa wiodła po wojnie nędzny żywot, otoczona aurą podejrzliwości i zaprzedania się wrogowi niemieckiemu. U Wojnowicza, podobnie jak u innych wskazanych wyżej twórców, Wielka Wojna Ojczyźniana stała się wielką legendą, wydarzeniem umieszczonym w sferze świętości, okresem dziejów również współcześnie wykorzystywanym, a wręcz eksploatowanym, dla stworzenia kolejnego mitu imperium radzieckiego.

W rzeczywistości postkomunistycznej nie zaistniał fakt najważniejszy: odbudowanie struktur wolności w ludzkich duszach i umysłach. Ludzie odczuwają nostalgię za dawnymi czasami, pragną powrotu do marzeń o raju na ziemi bądź o boskim Olimpie, gdzie podaje się nektar wiecznego żywota. Nie odbudowano w swych wnętrzach

\footnotetext{
Cвятое место nyсто, s. 2, [online] http://www.rg.ru/pamietnik.html, 25 II 2005.

\$1 W. Wojnowicz, Spizowa mitość..., s. 364.

82 В. Войнович, «Кумиротворение - это болезнь», s. 4-9, [online] http://www.aif.ru/onlineaif// 108003_01, 12 IV 2005.

83 W. Wojnowicz, Spiżowa mitość..., s. 192.
} 
dojrzałej świadomości, bazującej na podejmowaniu decyzji i wolnym wyborze. Ludzie nadal więc pozostają niewolnikami idealnymi, piastującymi w sobie ideę poddaństwa wobec każdego, kto zapewni im „nędzę w równości”, każąc kłaniać się kolejnym martwym idolom. Doskonale ilustrują to słowa jednego z bohaterów powieści - Admirała: Do niedawna żyliśmy w zoo. Wszyscy mieli swoje klatki. Drapieżniki swoje i roślinożerne swoje. Wszyscy mieszkańcy ogrodu zoologicznego marzyli naturalnie o wolności i chcieli się wyrwać z klatek. Teraz klatki nam otwarto. Wyszliśmy na wolność i okazato się, że za przyjemność biegania po trawce można zaptacić życiem [...] I napatrzywszy się na tę wolność, nacierpiawszy się strachu, myślimy sobie: czy nie lepiej powrócić do klatek, ale i drapieżników zamkną́ w niej znowu? ${ }^{84}$

Jak starano się wykazać powyżej, mitologia radziecka obecna była w życiu obywateli Kraju Rad od pierwszych dni po przewrocie październikowym. Mity o dzielnych herosach, Wodzu - Zeusie gromowładnym, Afrodytach wsiadających na traktory i odznaczanych za rekordowo szybką pracę, Atenach posiadających „mądrość” i wszechwiedzę Aleksandry Kołłontaj czy Nadieżdy Krupskiej towarzyszyły ludziom pragnącym uwierzyć w niemożliwe przez kilkadziesiąt lat istnienia reżimu. Szczególnie pociągający był, podsycany przez ideologię, mit ofiarnictwa, złożenia swego życia na ołtarzu „wielkiego ideału”. Zmitologizowanie niemal wszystkich sfer życia nie zaniknęło wraz z upadkiem ZSRR. Mit supermocarstwowości nadal odgrywa istotną rolę wśród tych, którzy tęsknią za imperium i pragną je odbudować. Wiąże się z tym mit silnego i wszechpotężnego władcy, uderzającego piorunami w nieposłusznych. Literatura rosyjska słusznie akcentuje, że mit stale przeplata się z utopią i quasi-religią. Demitologizacja natomiast to długi proces wiążący się z trwałymi zmianami w świadomości ludzkiej, proces, który może trwać jeszcze całe dziesięciolecia i albo przyniesie rezultaty w znalezieniu pozytywnego spoiwa cementującego naród, albo... powstanie nowa mitologia.

\section{BIBLIOGRAFIA}

Afanasjew J., Grożna Rosja, przeł. M. Kotowska, Warszawa 2005.

Aleksijewicz S., Czasy secondhand. Koniec czerwonego cztowieka, przeł. J. Czech, Wołowiec 2014.

Aleksijewicz S., Wojna nie ma w sobie nic z kobiety, przel. J. Czech, Wołowiec 2015.

Drużnikow J., Pawlika Morozowa wyniesienie na ottarze, [w:] J. Drużnikow, Rosyjskie mity. Od Puszkina do Pawlika Morozowa, przeł. F. Ociepka, M. Putrament, Warszawa 1998.

Duda K., „...chciat zakasać rękawy i zaczać budować nowy, duzy dom.... Roman Sienczyn - „Rodzina Jottyszewów", [w:] K. Duda, Szkice o prozie rosyjskiej XXI wieku. Ulicka, Szyszkin, Pielewin, Minajew, Sienczyn, Kuricyn, Starobiniec..., Kraków 2017.

Duda K., „Nowi Rosjanie” i statystyczny obywatel. Wspótczesna Rosja w literaturzepopularnej (Oksana Robski i Wiktoria Tokariewa), [w:] Kultura rosyjska w ojczyźnie i diasporze. Księga jubileuszowa dedykowana Profesorowi Lucjanowi Suchankowi, t. 2, red. K. Duda, Kraków 2008.

$84 \quad$ Tamże, s. 362. 
Duda K., Narody Kraju Rad. Wspótistnienie i zatomizowanie kultur (twórczość Ludmity Ulickiej), „Politeja” 2014, nr 5 (31/1).

Duda K., Socrealistyczna propaganda i postkomunistyczna pustka aksjologiczna (Wtadimir Wojnowicz: „Spiżowa mitość Agtai”), „Slavia Orientalis” 2008, nr 1.

Duda K., Wiara i naród. Twórczość Wtadimira Maksimowa, Kraków 2001.

Duda K., Wspótczesna literatura rosyjska wobec historii (nowy realizm Ludmity Ulickiej), „Prace Komisji Kultury Słowian PAU” 2008, t. 7: Kultura i polityka.

Dudek A., Groteska jako próba realizmu. O książe Wtadimira Wojnowicza „Życie i niezwykte przygody żotnierza Iwana Czonkina”, [w:] Emigracja i tamizdat. Szkice o wspótczesnej prozie rosyjskiej, red. L. Suchanek, Kraków 1993.

Dziekanowska M., Pamięć a tożsamość zbiorowa, [w:] Pamięć jako kategoria rzeczywistości spotecznej, red. J. Styka, M. Dziekanowska, Lublin 2012.

Furet F., Przesztośćpewnego ztudzenia. Esejo idei komunistycznej w XX wieku, przeł. J. Górnicka-Kalinowska, M. Ochab, Warszawa 1996.

Gajda J., Upadek imperium. Nauka dla wspótczesnej Rosji, przeł. H. Chłystowski, Warszawa 2015. Gieysztor A., Mitologia Stowian, Warszawa 2006.

Hartmann Ch., Wielka Wojna Ojczyźniana 1941-1945, przeł. B. Ostrowska, Poznań 2014.

Heller M., Maszyna i śrubki. Jak hartowat się cztowiek radziecki, Warszawa 1989.

Heller M., Niekricz A., Utopia u wtadzy. Historia Zwiazku Sowieckiego, t. 2, przeł. A. Mietkowski, Wrocław 1989.

Jegorow B., Oblicza Rosji. Szkice z historii kultury Rosji XIX wieku, przeł. D. i B. Żyłkowie, Gdańsk 2002.

Klik M., Teorie mitu. Wspótczesne literaturoznawstwo francuskie (1969-2010), Warszawa 2016.

Leontjewa O., Badania nad pamięcia historyczna we wspótczesnej nauce rosyjskiej, przeł. A. Jaskólski, „Rocznik Instytutu Europy Środkowo-Wschodniej” 2015, z. 2.

Malia M., Sowiecka tragedia. Historia komunistycznego imperium rosyjskiego 1917-1991, przeł. M. Hułas, E. Wyzner, Warszawa 1998.

Miller A., Polityka pamięci w Rosji. Rola czynników niepaństwowych, przeł. A. Jaskólski, „Rocznik Instytutu Europy Środkowo-Wschodniej” 2015, z. 2.

Olędzka J., Rola pamięci o Wielkiej Wojnie Ojczyźnianej w strategii utrwalania jedności narodu rosyjskiego, „Studia Podlaskie” 2016, t. 24.

Overy R., Krew na śniegu. Rosja w II wojnie światowej, przeł. M. i T. Luftnerowie, Gdańsk 1999. Pasternak B., Doktor Żywago, przeł. D. Chróścielewska, Warszawa 1990.

Pawłowski T., Mit „Wielkiej Wojny Ojczyźnianej”, [online] http://historia.wp.pl/title.MitWielkiej-Wojny-Ojczyznianej.wid.1, 27 III 2017.

Pazio-Wlazłowska D., Pamięć Wielkiej Wojny Ojczyźnianej w narracjach mtodzieży, „Politeja” 2015, nr 3 (35).

Pietrzycka-Bohosiewicz K., Ocalić Rosję za cenę Rosji... „Generat i jego armia”, [w:] K. Pietrzycka-Bohosiewicz, W poszukiwaniu autentyzmu. Twórczość prozatorska Gieorgija Wtadimowa, Kraków 1999.

Pipes R., Rosja bolszewików, przeł. W. Jeżewski, Warszawa 2005.

Radziński E., Stalin, przeł. I. Lewandowska, M. Jagiełło, Warszawa 1996.

Remnick D., Zmartwychwstanie. Walka o nowa Rosje, przeł. M. Słysz, Warszawa 1997. 
Sadowski J., Dokąd zmierzasz, trojko?, „Znak” 2005, nr 10.

Sadowski J., Rewolucja i kontrrewolucja obyczajów. Rodzina, prokreacja i przestrzeń życia w rosyjskim dyskursie utopijnym lat 20. i 30. XX wieku, Łódź 2005.

Senczin R., Rodzina Jottyszewów, przeł. M. Hornung, Warszawa 2015.

Smaga J., Rosja w 20 stuleciu, Kraków 2002.

Sokołow B., Prawdy i mity Wielkiej Wojny Ojczyźnianej 1941-1945, przeł. J. Stroganova, A. Sawinkow, Kraków 2015.

Sokołow B., Wielka wojna mitów, czyli jak ZSRR ukrywato prawdę o II wojnie światowej, „Newsweek" 2014, 21 VI.

Sołżenicyn A., Rosja w zapaści, przeł. J. Zychowicz, Warszawa 1999.

Suchanek L., Anioty, biesy i prawda. Pisarstwo Jurija Drużnikowa, Kraków 2007.

Suchanek L., Mur. O zapiskach Wiktora Niekrasowa, [w:] Emigracja i tamizdat. Szkice o wspótczesnej prozie rosyjskiej, red. L. Suchanek, Kraków 1993.

Szacka B., Czas przeszty, pamięć i mit, Warszawa 2006.

Szacki J., Spotkania z utopia, Warszawa 2000.

Tokariewa W., Mitość na cate życie, przeł. I. Lewandowska, Warszawa 2006.

Ulicka L., Przypadek doktora Kukockiego, przeł. B. Reszko, Warszawa 2006.

Wielka wojna mitów, czyli jak ZSRR ukrywato prawdę o II wojnie światowej, wywiad I.T. Miecika z B. Sokołowem, „Newsweek Historia” 2013, nr 12.

Wojnowicz W., Spiżowa mitość Agtai, przeł. H. Broniatowska, Warszawa 2006.

Wojnowicz W., Życie i niezwykte przygody żotnierza Iwana Czonkina, przeł. W. Dłuski, Chotomów 1990.

Ziółek P., Idea imperium, Warszawa 1997.

Бойм С., Общие места, Москва 2002.

Войнович В., «Кумиротворение - это болезнь», [online] http://www.aif.ru/onlineaif// 108003_01.

„Комсомольская правда” 2000, 21 апреля, [online] http://magazines.rus.ru/volga/recens.html. Монумкнтальная контрпропаганда, [online] https://newizv.ru/news/society/14-09-2004/ 11319-monumentalnaja-kontrpropaganda.

Немцев М., Горе vs. Гордость в постпамяти, [online] http://gefter.ru/archive/18020, 4 VII 2017. Cвsmoе место nyсmo, [online] http://www.rg.ru/pamietnik.html.

Сергеева А., Русские. Стереотипь поведения, традиции ментальность, Москва 2005.

Prof. dr hab. Katarzyna DUDA - humanistka, kulturoznawca, literaturoznawca. Pracownik Instytutu Rosji i Europy Wschodniej UJ. Autorka książek: Antyutopia w literaturze rosyjskiej XX wieku (1995), Wiara i naród. Twórczość Wtadimira Maksimowa (2001), Andriej Amalrik - rosyjski dysydent (2010), Szkice o prozie rosyjskiej XXI wieku. Ulicka, Szyszkin, Pielewin, Minajew, Sienczyn, Kuricyn, Starobiniec... (2017). Członek Komisji Kultury Słowian PAU, Komisji Emigrantologii Słowian, Międzynarodowego Komitetu Słowianoznawstwa oraz Komitetu Redakcyjnego czasopisma „Emigrantologia Słowian”. 